\title{
Structural studies of pyoverdins with cyclopeptidic substructures by electrospray ionization and collision induced fragmentation ${ }^{1,2}$
}

\author{
Regine Fuchs and Herbert Budzikiewicz* \\ Institut für Organische Chemie der Universität zu Köln, Greinstr. 4, 50939 Köln, Germany
}

\section{Dedicated to the memory of Dr. Piet Leclercq}

\begin{abstract}
By collision induced fragmentation of the $[\mathrm{M}+2 \mathrm{H}]^{2+}$-ions of pyoverdins with a partially cyclic peptide structure the nature of the amino acids present and their sequence can be determined. The results obtained with pyoverdins of known structure could be used for structure proposals for new representatives.
\end{abstract}

Keywords: Bacterial siderophores, pyoverdins, electrospray ionization mass spectrometry

\section{Introduction}

Fluorescent members of the rRNA homology group I of the bacterial genus Pseudomonas are characterized by the production of iron chelating metabolites, so-called pyoverdins. The pyoverdins consist of a dihydroxyquinoline chromophore bound amidically to the N-terminus of a peptide chain comprising 6 to 12 amino acids, L as well as D, and partially modified, and to a small dicarboxylic acid or its monoamide [2], viz. succinic acid and succinamide, malic acid and malamide, Glu and 2-ketoglutaric acid. By now about 50 pyoverdins are known and for more than 40 complete or fairly complete structures have been established [3]. The peptide chain has a two-fold function. It provides two of the ligand sites for $\mathrm{Fe}^{3+}$, and it is responsible for the recognition of the iron complex at the surface of the producing cell. Pyoverdins can roughly be divided into four structural sub-groups:

(1) the most common variety has cOHOrn as the C-terminal amino acid (cf. [4]);

(2) the group second in number is characterized by a $\mathrm{C}$-terminal cyclic part consisting of 3 or 4 amino acids, formed by an amide bond between the carboxyl group of the C-terminal amino acid and the $\varepsilon$-amino group of an in-chain Lys (cf. [5,6]);

\footnotetext{
${ }^{1}$ Part XCVI of the series "Microbial metabolites". For part XCV see [1].

${ }^{2}$ Abbreviations used: Common amino acids, 3-letter code in the text, 1-letter code in the designation of fragments; Fho $\left(\mathrm{O}^{\prime}\right)$ indicates $\mathrm{N}^{5}$-formyl- $\mathrm{N}^{5}$-hydroxy Orn; Chr, pyoverdin chromophore; Suc, Suca, Kgl, succinic acid, succinamide, 2-ketoglutaric acid side chain.

${ }^{*}$ Corresponding author: Prof. Dr. H. Budzikiewicz. Fax: +49 221470 5057, E-mail: h.budzikiewicz@ uni-koeln.de.
} 
(3) a small number has a C-terminal cyclodepsipeptidic substructure formed by an ester bond between the carboxyl group of the C-terminal amino acid and an in-chain Ser or Thr (cf. [7]);

(4) several pyoverdins have a C-terminal free carboxyl group; some or all of them may be hydrolysis products of the rather labile cyclic esters (group 3 ) which are readily hydrolyzed at $\mathrm{pH}$ values $>9$ (cf. [7]).

The amino acid sequence of the groups (1) and (4) can be established by the mass spectrometric methods developed for peptide analysis [8]. Due to the preferred charge stabilization in the quinoline chromophore mainly B-ions [9] are observed unless easily protonated amino acids such as Arg are present. In this case also abundant $Y^{\prime \prime}$-ions will be formed. Members of group (3) can be analyzed after hydrolytic or reductive opening of the ester bond [7]. For pyoverdins belonging to group (2) typical peptide fragmentation occurs only up to the amino acid carrying the cyclic C-terminal substructure. An approach how to determine the nature and the sequence of the amino acids in these cycles will be presented here.

The mass spectrometric analysis of cyclopeptides starting from $\mathrm{M}^{+}$(electron ionization, EI) as well as from $[\mathrm{M}+\mathrm{H}]^{+}$(fast atom bombardment, FAB; electrospray ionization, ESI, etc.) has been discussed in detail [10]. Primary cleavage of the various peptide bonds with comparable rates leads to a number of isomeric linear species which can be distinguished only by secondary fragmentation processes after the loss of amino acid or peptide units. Degradation sequences, e.g., by collision activation (CA) techniques of selected ions will finally give sequentional information [11]. A further problem not relevant for the analysis of linear peptides is the distinction between sequence and retro-sequence. Provided the appropriate processes can be observed with sufficient abundance, fragmentation, e.g., of A-ions $\left(\mathrm{NH}_{2}-\right.$ $\mathrm{CHR}-\mathrm{CO} \sim \sim \sim \mathrm{CO}-\mathrm{NH}-\mathrm{CHR}^{+}$) after $\mathrm{CA}$ can be used for this purpose: elimination of NH-CHR-CO will be induced from the $\mathrm{N}$-terminus and that of $\mathrm{NH}-\mathrm{CHR}^{\prime}$ from the $\mathrm{C}$-terminus.

\section{Experimental}

The mass spectral analyses were performed with a MAT 900 ST instrument with an EBT geometry equipped with an ESI II ion source (Finnigan MAT, Bremen, Germany); spray voltage 3.4-3.6 kV, capillary temperature $230^{\circ} \mathrm{C}$, collision gas He. The samples were dissolved in a mixture consisting of water, methanol and acetic acid 50:50:0.1 (v/v). All masses given in the text are nominal masses.

\section{Results and discussion}

\subsection{Pyoverdins with a cyclotripeptidic C-terminal part}

\subsubsection{Pyoverdin Pf 13525}

In the present investigation molecular or quasi-molecular ions were selected after ESI by the magnetic analyzer of the MAT 900ST instrument. In this way impure samples and even crude extracts can be analyzed. They were subjected to CA either in the octapole unit in the transfer region in front of the ion trap, or in the ion trap. The two techniques give different information due to the differing residence times of the ions and the different amounts of energy transferred. In the octapole consecutive fragmentations may occur giving superimposed spectra, while in the ion trap fragment ions can be selected and by CA be induced to further fragmentation, a process that can be repeated several times $\left(\mathrm{MS}^{n}\right)$. The collision energy determines the degree of fragmentation. The approach will be demonstrated using the pyoverdin 


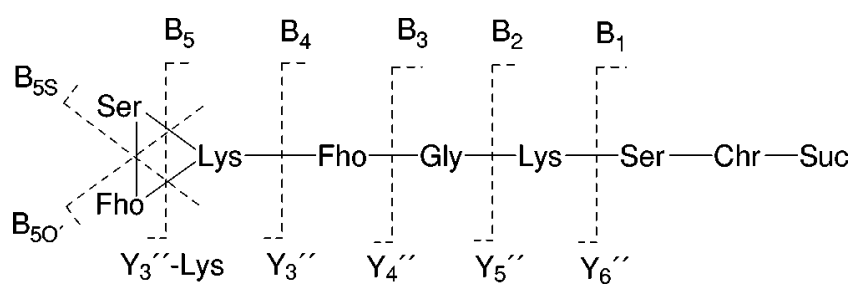

Fig. 1. Structure of pyoverdin Pf 13525 with a succinic acid side chain (1) and scheme for the characterization of fragments. Note: Contrary to the usual way of presentation pyoverdins are depicted with the N-terminus of the peptide chain bound to the chromophore on the right-hand side.

Pf 13525 (1, Fig. 1) [12] as an example and the results will than be transferred to other pyoverdins. The fragmentation processes discussed below could be corroborated in the following way: Comparison of the mass spectra of 1 with those of an analogous compound labeled in all positions with ${ }^{15} \mathrm{~N}$ [13] allows to determine the number of $\mathrm{N}$-atoms present in a given fragment. For the description of the characteristic fragments the nomenclature by Roepstorff and Fohlman [9] will be extended as depicted in Fig. 1. The $\mathrm{N}$-terminal ions are numbered up to the branching Lys $\left(\mathrm{B}_{5}\right)$. Ions arising from the cleavage of the cyclic part are designated by adding the one-letter symbol of the amino acid attached to Lys (e.g., $\mathrm{B}_{5 \mathrm{~S}}$ means $\mathrm{B}_{5}+$ Ser).The masses of the fragments stemming from the cyclic part of the molecule $\left(\mathrm{B}_{5}, \mathrm{~B}_{5 \mathrm{~S}}, \mathrm{~B}_{5 \mathrm{O}^{\prime}}\right)$ are calculated as if they came from a linear peptide. E.g., $\mathrm{B}_{5}$ requires the addition of one $\mathrm{H}$ to the $\varepsilon$-amino group of the Lys unit. Ions without a charge symbol are singly charged. Doubly charged ions are characterized as such (e.g., $\mathrm{B}_{5}^{2+}$ ).

The pyoverdin 1 in the positive ESI mass spectrum yields $[\mathrm{M}+2 \mathrm{H}]^{2+}(100 \%$ rel. int. $)$ and $[\mathrm{M}+\mathrm{H}]^{+}$ (4\%). The CA spectra of both species in the octapole unit give essentially the same results, viz. a very abundant $\mathrm{A}_{1}$ and a host of its further degradation products, as well as several ions characteristic for Lys $\left(\mathrm{NH}_{2}-\left(\mathrm{CH}_{2}\right)_{4}-\mathrm{CH}\left(\mathrm{NH}_{2}\right)-\mathrm{CO}^{+}, m / z 129 ;-\mathrm{CO}, m / z 101 ;-\mathrm{NH}_{3}, m / z, 84\right)$ and of Fho $(\mathrm{CHO}-\mathrm{N}(\mathrm{OH})-$ $\left(\mathrm{CH}_{2}\right)_{3}-\mathrm{CH}\left(\mathrm{NH}_{2}\right) \mathrm{CO}^{+}, \mathrm{m} / 2,159$ plus ions formed by combinations of losses of $\mathrm{CO}, \mathrm{NH}_{3}$ and $\mathrm{H}_{2} \mathrm{O}, \mathrm{m} / \mathrm{z}$ $131,114,113,86$ and 68), all of low abundance (these ions are also observed with low abundance in the octapole CA spectra of other pyoverdins containing Lys and Fho; they will not again be mentioned there). Information regarding the cycle cannot be obtained.

$\mathrm{CA}$ of $[\mathrm{M}+\mathrm{H}]^{+}$in the ion trap (Fig. 2 and Table 1) gives more sequential information. An investigation of the singly charged ion has the advantage that only singly charged daughter ions will be obtained. This facilitates the interpretation since in the trap monoisotopic ions are investigated and in the absence of an isotope pattern no check is available for the state of charge. From higher charged precursors both singly and multiply charged fragments can be formed. With low collision energies essentially B-ions up to $\mathrm{B}_{4}$ (cleavage after the last amino acid before the cycle) with relative intensities between 1 and $5 \%$ are observed. Increase of the energy results in the formation of additional $\mathrm{A}-$ and $\mathrm{C}^{\prime \prime}$-ions and in losses of small neutral molecules $\left(\mathrm{CO}, \mathrm{H}_{2} \mathrm{O}, \mathrm{NH}_{3}\right)$ (Fig. 2). The amino acid sequence of the linear part of $\mathbf{1}$ can be deduced from these data, but no ions are observed which stem from fragmentation of the cycle.

On the first glance this is surprising, since in ESI ion trap CA investigations of cyclopeptides and also of peptides with partially linear and partially cyclic structure fragmentation of the cycle had been observed [11,14]. If, however, one considers the evidence accumulated on the influence of the protonation sites with respect to fragment formation, the following picture emerges. Protonation of an amidic nitrogen weakens the amide bond and fosters its cleavage [15]. Whether one considers the mobile proton model $[16,17]$ which postulates a proton mobility along the peptide chain, or a mixture of peptide molecules protonated at different loci [18], is of no importance. Both models explain the cleavage of 

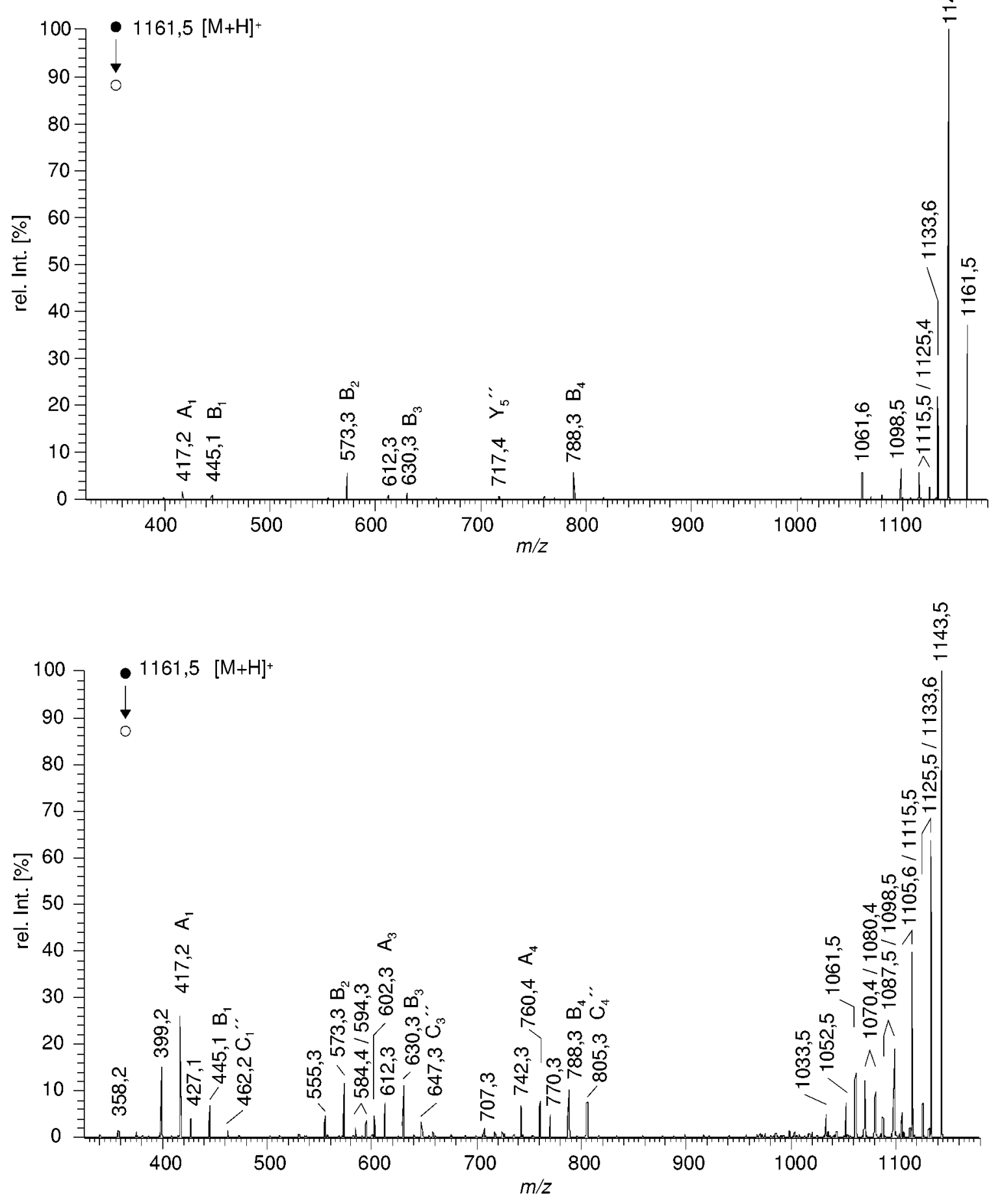

Fig. 2. Ion trap CA (top 30\%, bottom 50\% relative collision energy) spectrum of $[\mathrm{M}+\mathrm{H}]^{+}$of $\mathbf{1}$. 
Table 1

Ions observed in the ion trap CA spectrum of $[\mathrm{M}+\mathrm{H}]^{+}$of $\mathbf{1}$ (ions observed in both spectra are printed in bold, ions observed only in the lower spectrum are printed in italic)

\begin{tabular}{|c|c|c|c|c|c|}
\hline $\mathrm{m} / \mathrm{z}$ & Fragments & $\mathrm{m} / \mathrm{z}$ & Fragments & $m / z$ & Fragments \\
\hline 358 & $B_{0}$ & 612 & $\mathrm{~B}_{3}-\mathrm{H}_{2} \mathrm{O}$ & 1052 & {$\left[\mathrm{M}+\mathrm{H}-2 \mathrm{CO}-2 \mathrm{H}_{2} \mathrm{O}-\mathrm{NH}_{3}\right]^{+}$} \\
\hline 399 & $\mathrm{~A}_{1}-\mathrm{H}_{2} \mathrm{O}$ & 630 & $\mathbf{B}_{3}$ & 1061 & {$[\mathbf{M}+\mathbf{H}-\mathbf{S u c}]^{+}$} \\
\hline 417 & $\mathrm{~A}_{1}$ & 647 & $\mathbf{C}_{3}^{\prime \prime}$ & 1070 & {$\left[\mathrm{M}+\mathrm{H}-2 \mathrm{CO}-\mathrm{H}_{2} \mathrm{O}-\mathrm{NH}_{3}\right]^{+}$} \\
\hline 427 & $\mathrm{~B}_{1}-\mathrm{H}_{2} \mathrm{O}$ & 707 & $\mathrm{~A}_{4}-\mathrm{NH}_{3}-2 \mathrm{H}_{2} \mathrm{O}$ & 1080 & {$\left[\mathrm{M}+\mathrm{H}-\mathrm{CO}-2 \mathrm{H}_{2} \mathrm{O}-\mathrm{NH}_{3}\right]^{+}$} \\
\hline 445 & $\mathbf{B}_{1}$ & 742 & $\mathrm{~A}_{4}-\mathrm{H}_{2} \mathrm{O}$ & 1087 & {$\left[\mathrm{M}+\mathrm{H}-2 \mathrm{CO}-\mathrm{H}_{2} \mathrm{O}\right]^{+}$} \\
\hline 462 & $C_{1}^{\prime \prime}$ & 760 & $A_{4}$ & 1098 & {$\left[\mathrm{M}+\mathrm{H}-\mathrm{CO}-\mathrm{H}_{2} \mathrm{O}-\mathrm{NH}_{3}\right]^{+}$} \\
\hline 555 & $\mathrm{~B}_{2}-\mathrm{H}_{2} \mathrm{O}$ & 770 & $\mathrm{~B}_{4}-\mathrm{H}_{2} \mathrm{O}$ & 1105 & {$[\mathrm{M}+\mathrm{H}-2 \mathrm{CO}]^{+}$} \\
\hline 573 & $\mathbf{B}_{2}$ & 788 & $\mathbf{B}_{4}$ & 1115 & {$\left[\mathrm{M}+\mathrm{H}-\mathrm{CO}-\mathrm{H}_{2} \mathrm{O}\right]^{+}$} \\
\hline 584 & $\mathrm{~A}_{3}-\mathrm{H}_{2} \mathrm{O}$ & 805 & $C_{4}^{\prime \prime}$ & 1125 & {$\left[\mathbf{M}+\mathbf{H}-2 \mathbf{H}_{2} \mathbf{O}\right]^{+}$} \\
\hline 594 & $\mathrm{~B}_{3}-2 \mathrm{H}_{2} \mathrm{O}$ & 1033 & {$[M+H-C O-S u c]^{+}$} & 1133 & {$[\mathbf{M}+\mathbf{H}-\mathbf{C O}]^{+}$} \\
\hline 602 & $A_{3}$ & & & 1143 & {$\left[\mathbf{M}+\mathbf{H}-\mathbf{H}_{2} \mathbf{O}\right]^{+}$} \\
\hline
\end{tabular}

the various peptide bonds. If, however, the charge is located outside the peptide backbone as in ammonium or phosphonium salts $[19,20]$ or when a strongly basic amino acid (Arg and to a lesser degree His and Lys) (e.g., [18]) is present, fragmentation will occur by charge-remote processes (e.g., Fig. 3) [21] (the ion structure differs from that of the "classical" B-ions where the charge is located on the carbonyl group) which are less efficient than the direct proton induced cleavage. The chromophore of $\mathbf{1}$ due to the extended aromatic system stabilizes preferentially the first ionizing proton. This is in agreement with the observation that only N-terminal fragments are formed. A second proton forming $[\mathrm{M}+2 \mathrm{H}]^{2+}$ can be located anywhere in the peptide chain and thus fragmentation in the linear part as well as in the cycle may be expected.

The CA spectrum of $[\mathrm{M}+2 \mathrm{H}]^{2+}$ clearly shows many more fragments (Fig. 4 and Table 2) than its singly charged counterpart (Table 1), including several fragments formed by cleavage of the ring structure. B-, A- and $\mathrm{C}^{\prime \prime}$-ions are accompanied by species which are formed by the loss of small neutral particles $\left(\mathrm{NH}_{3}, \mathrm{H}_{2} \mathrm{O}, \mathrm{CO}, \mathrm{CO}_{2}\right)$ derived from the linear part. They confirm the conclusions obtained from $[\mathrm{M}+\mathrm{H}]^{+}$. Localization of the second proton in the cyclic part of the molecule is evidenced by the observation of $Y_{3}^{\prime \prime}(\mathrm{m} / z$ 374). Ring opening is demonstrated by the formation of an ion corresponding to $\mathbf{B}_{5}(\mathrm{~m} / z$ 916). It comprises Lys incorporated in the ring. This requires cleavage of two amide bonds and attachment of one $\mathrm{H}$ to the $\varepsilon$-amino function of Lys. The correctness of this assignment could be demonstrated by the $\mathrm{MS}^{3}$ spectrum of this ion yielding the sequence of $\mathrm{B}$-ions down to $\mathrm{B}_{1}$ as well as $\mathrm{A}_{1}$ plus several losses of small neutrals (Fig. 5).

Protonation of the Lys-Fho amide bond ( $\mathrm{Lys}-\mathrm{CONH}_{2}^{+}-\mathrm{Fho}$ ) will result in the formation (I) of a B-ion (Lys- $\mathrm{CO}^{+}$, possibly stabilized by interaction with the preceding amide oxygen under formation of an oxazolinone ring, cf. $[22,23]$ ) as well as (II) of a $\mathrm{Y}^{\prime \prime}$-ion (transfer of the Lys- $\alpha-\mathrm{NH}$ to the Fho- $\mathrm{NH}_{2}^{+}$, cf. [24]) (Fig. 6). Starting from the B-ion charge-remote elimination of Fho gives $\mathrm{B}_{5 \mathrm{~S}}^{2+}(\mathrm{m} / \mathrm{z}, 502)$ and that of Ser-Fho gives $B_{5}^{2+}(\mathrm{m} / z$ 458.5) (cf. [23]) by cleavage of the respective amide bonds with transfer of one $\mathrm{H}$ (B-type fragmentation). Alternative cleavage of the CO-CHR bond (A-type fragmentation) leads to $\left[\mathrm{B}_{5 \mathrm{~S}}+\mathrm{CO}\right]^{2+}(\mathrm{m} / \mathrm{z} 516)$.

In contrast to the $\mathrm{B}$-ion the decay of the $\mathrm{Y}^{\prime \prime}$-ion can be induced according to the mobile-proton model by the protonated amide bonds leading to singly charged $\mathbf{B}_{5 \mathrm{~S}}(\mathrm{~m} / \mathrm{z}, 1003)$ and $\mathbf{B}_{5}(\mathrm{~m} / \mathrm{z} 916)$. Again, alternative cleavage of the CO-CHR bonds leads to the corresponding $+\mathrm{CO}$ ions $(\mathrm{m} / z 944$ and 1031). Primary cleavage of the protonated Lys-Ser and Ser-Fho bonds initiates analogous fragmentation processes. The 

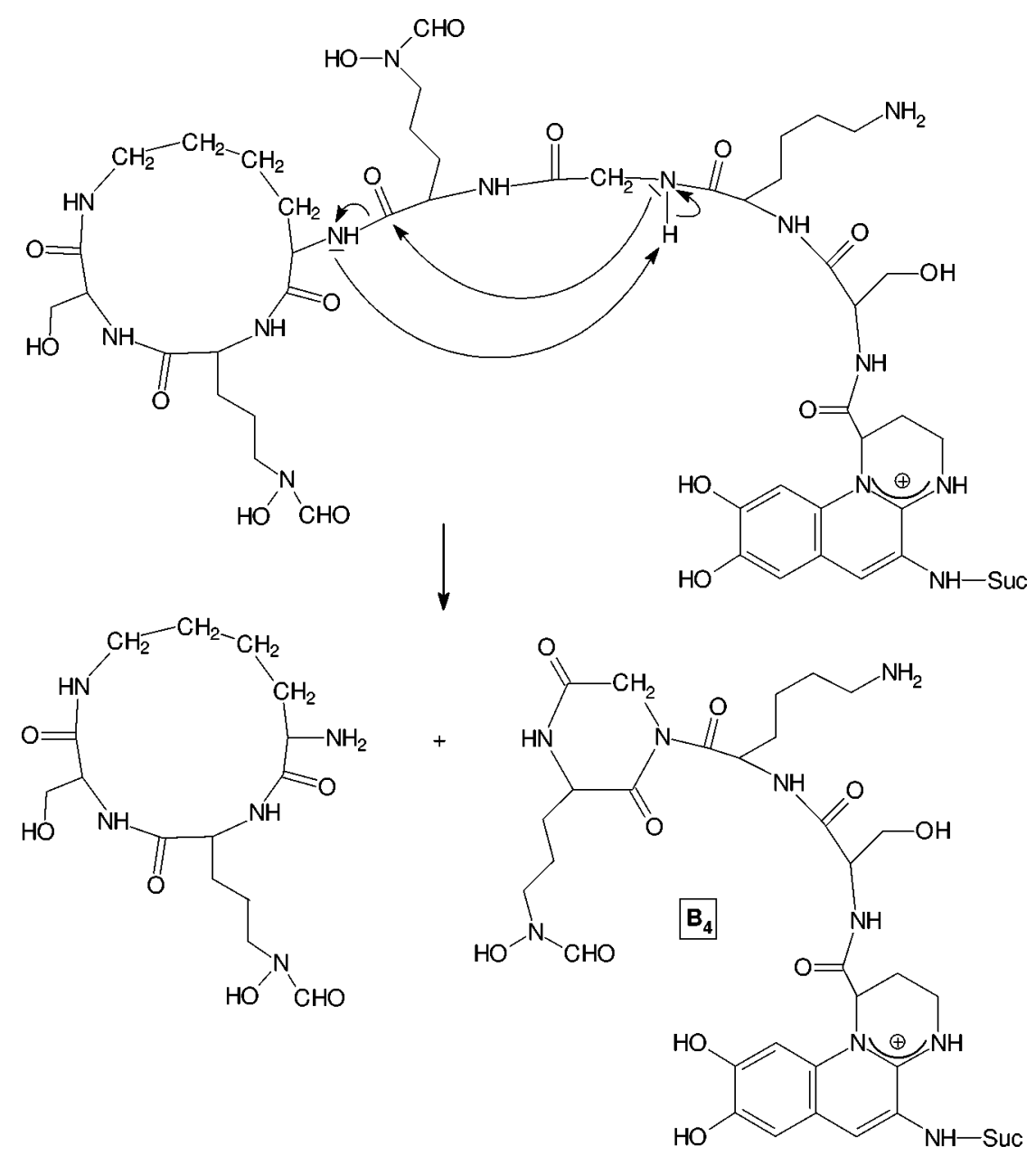

Fig. 3. Charge-remote-induced formation of the $\mathrm{B}_{4}$-ion from $[\mathrm{M}+\mathrm{H}]^{+}$of $\mathbf{1}$.

additional fragments $\mathrm{B}_{5 \mathrm{O}^{\prime}}$ and $\mathrm{A}_{5 \mathrm{O}^{\prime}}$ can be obtained in this way. Primary cleavage of the $\mathrm{NH}-\mathrm{CHR}$ bonds leads to the corresponding $\mathrm{C}_{5 \mathrm{~S}}^{\prime \prime}$-fragment $(\mathrm{m} / \mathrm{z}, 1020)$.

From the observation of $\mathrm{B}_{5}, \mathrm{~B}_{5 \mathrm{~S}}$ and $\mathrm{B}_{5 \mathrm{O}^{\prime}}$ it follows that the $\mathrm{C}$-terminal ring is linked to the peptide chain via Lys and that Ser as well as Fho is bound to Lys completing the structure. The CA spectrum of $\mathrm{Y}_{3}^{\prime \prime}(\mathrm{m} / \mathrm{z}$ 374) confirms the conclusions derived from the analysis of the $\mathrm{N}$-terminal fragments. Losses of Fho and of Ser in combination with several small neutral particles $\left(\mathrm{NH}_{3}\right.$, etc.) can be seen.

A distinction between sequence and retro-sequence (Lys-Fho-Ser or Lys-Ser-Fho) according to [10] could be possible by CA of secondary fragments of the A- or $\mathrm{C}^{\prime \prime}$-type (see above). In the case of $1 \mathrm{CA}$ of $\mathrm{A}_{5 \mathrm{O}^{\prime}}^{2+}\left(\mathrm{m} / \mathrm{z}\right.$ 523.5) giving $\mathrm{B}_{5}^{2+}$ demonstrates that Fho is directly connected to Lys (Fig. 7 and Table 3). It should be mentioned here that in the ion trap CA spectra mainly B-type ions are observed. A- and $\mathrm{C}^{\prime \prime}$-ions are less common and usually of lower abundance; thus, an unambiguous result regarding sequence/retrosequence problem will not be possible for every pyoverdin (see also below).

Fragments arising from the cleavage of the amide bonds do not allow to decide in which way the branching Lys is incorporated into the pyoverdin, whether bound with the $\alpha$-amino group to the linear part and with the $\varepsilon$-amino group into the cycle (as depicted for $\mathbf{1}$ ) or vice versa. That the direction as in 

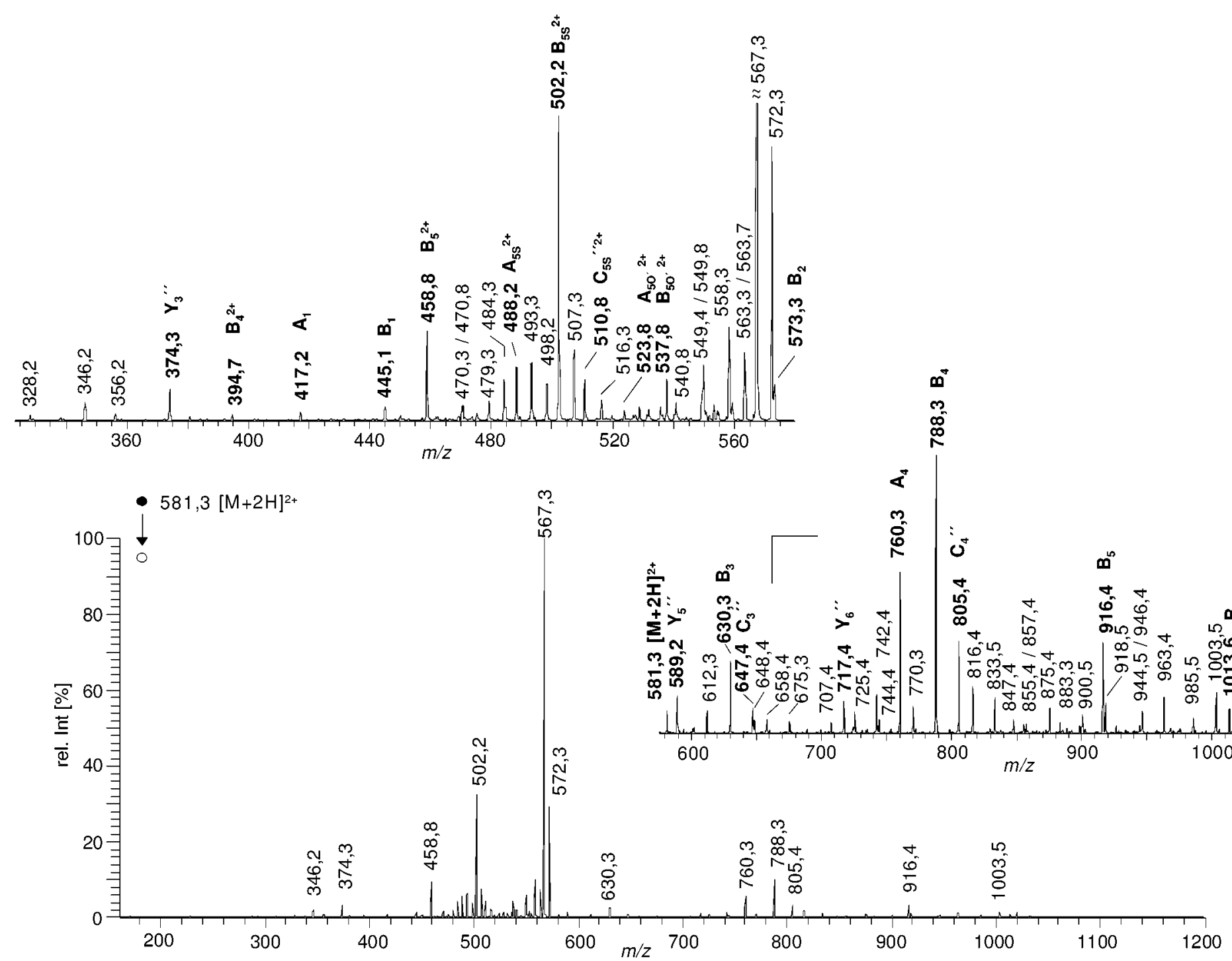

Fig. 4. Ion trap CA spectrum of $[\mathrm{M}+2 \mathrm{H}]^{2+}$ of $\mathbf{1}$ (sequence relevant ions in bold). 
Table 2

Ions observed in the ion trap CA spectrum of $[\mathrm{M}+2 \mathrm{H}]^{2+}$ of $\mathbf{1}$ (rearrangement products in italic)

\begin{tabular}{|c|c|c|c|c|c|}
\hline $\mathrm{m} / \mathrm{z}$ & Fragments & $m / z$ & Fragments & $m / z$ & Fragments \\
\hline 328 & $\mathrm{Y}_{3}^{\prime \prime}-\mathrm{CO}-\mathrm{H}_{2} \mathrm{O}$ & 558 & {$\left[\mathrm{M}+2 \mathrm{H}-\mathrm{CO}-\mathrm{H}_{2} \mathrm{O}\right]^{2+}$} & 847 & $\mathrm{~A}_{4}+\mathrm{Ser}$ \\
\hline 346 & $\mathrm{Y}_{3}^{\prime \prime}-\mathrm{CO}$ & 563 & {$\left[\mathrm{M}+2 \mathrm{H}-2 \mathrm{H}_{2} \mathrm{O}\right]^{2+}$} & 855 & $\mathrm{~A}_{4}+$ Fho- $\mathrm{CO}-\mathrm{NH}_{3}-\mathrm{H}_{2} \mathrm{O}$ \\
\hline 356 & $\mathrm{Y}_{3}^{\prime \prime}-\mathrm{H}_{2} \mathrm{O}$ & 563.5 & {$\left[\mathrm{M}+2 \mathrm{H}-\mathrm{H}_{2} \mathrm{O}-\mathrm{NH}_{3}\right]^{2+}$} & 857 & $\mathrm{~B}_{4}+\mathrm{Ser}-\mathrm{H}_{2} \mathrm{O}$ \\
\hline 374 & $Y_{3}^{\prime \prime}$ & 567 & {$[\mathrm{M}+2 \mathrm{H}-\mathrm{CO}]^{2+}$} & 875 & $B_{4}+S e r$ \\
\hline 394.5 & $\mathrm{~B}_{4}^{2+}$ & 572 & {$\left[\mathrm{M}+2 \mathrm{H}-\mathrm{H}_{2} \mathrm{O}\right]^{2+}$} & 883 & $\mathrm{~A}_{4}+\mathrm{Fho}-\mathrm{NH}_{3}-\mathrm{H}_{2} \mathrm{O}$ \\
\hline 417 & $\mathrm{~A}_{1}$ & 573 & $\mathrm{~B}_{2}$ & 900 & $\mathrm{~A}_{4}+\mathrm{Fho}-\mathrm{H}_{2} \mathrm{O}$ \\
\hline 445 & $\mathrm{~B}_{1}$ & 589 & $\mathrm{Y}_{5}^{\prime \prime}$ & 916 & $\mathrm{~B}_{5}$ \\
\hline 458.5 & $\mathrm{~B}_{5}^{2+}$ & 612 & $\mathrm{~B}_{3}-\mathrm{H}_{2} \mathrm{O}$ & 918 & $A_{4}+F h o$ \\
\hline 470 & $\mathrm{~A}_{5 \mathrm{~S}}-2 \mathrm{H}_{2} \mathrm{O}^{2+}$ & 630 & $\mathrm{~B}_{3}$ & 944 & $\mathrm{~B}_{5}+\mathrm{CO}$ \\
\hline 470.5 & $\mathrm{~A}_{5 \mathrm{~S}}-\mathrm{H}_{2} \mathrm{O}-\mathrm{NH}_{3}^{2+}$ & 647 & $\mathrm{C}_{3}^{\prime \prime}$ & 946 & $B_{4}+F h o$ \\
\hline 479 & $\mathrm{~A}_{5 \mathrm{~S}}-\mathrm{H}_{2} \mathrm{O}^{2+}$ & 648 & $\mathrm{~B}_{3}+\mathrm{H}_{2} \mathrm{O}$ & 963 & $C_{4}^{\prime \prime}+F h o$ \\
\hline 484 & $\mathrm{~B}_{5 \mathrm{~S}}-2 \mathrm{H}_{2} \mathrm{O}^{2+}$ & 658 & $\mathrm{~B}_{3}+\mathrm{CO}$ & 985 & $\mathrm{~B}_{5 \mathrm{~S}}-\mathrm{H}_{2} \mathrm{O}$ \\
\hline 488 & $\mathrm{~A}_{5 \mathrm{~S}}^{2+}$ & 675 & $\mathrm{C}_{3}^{\prime \prime}+\mathrm{CO}$ & 1003 & $\mathrm{~B}_{5 \mathrm{~S}}$ \\
\hline 493 & $\mathrm{~B}_{5 \mathrm{~S}}-\mathrm{H}_{2} \mathrm{O}^{2+}$ & 707 & $\mathrm{~A}_{4}-2 \mathrm{H}_{2} \mathrm{O}-\mathrm{NH}_{3}$ & 1013 & $\mathrm{~B}_{5 \mathrm{~S}}-\mathrm{H}_{2} \mathrm{O}+\mathrm{CO}$ \\
\hline 498 & $\mathrm{~B}_{5 \mathrm{~S}}+\mathrm{CO}-2 \mathrm{H}_{2} \mathrm{O}^{2+}$ & 717 & $\mathrm{Y}_{6}^{\prime \prime}$ & 1020 & $\mathrm{C}_{5 \mathrm{~S}}^{\prime \prime}$ \\
\hline 502 & $\mathrm{~B}_{5 \mathrm{~S}}^{2+}$ & 725 & $\mathrm{~A}_{4}-\mathrm{H}_{2} \mathrm{O}-\mathrm{NH}_{3}$ & 1031 & $\mathrm{~B}_{5 \mathrm{~s}}+\mathrm{CO}$ \\
\hline 507 & $\mathrm{~B}_{5 \mathrm{~S}}+\mathrm{CO}-\mathrm{H}_{2} \mathrm{O}^{2+}$ & 742 & $\mathrm{~A}_{4}-\mathrm{H}_{2} \mathrm{O}$ & 1033 & $B_{4}+F h o+S e r$ \\
\hline 510.5 & $\mathrm{C}_{5 \mathrm{~S}}^{\prime \prime 2+}$ & 744 & $\mathrm{~B}_{4}-\mathrm{CO}_{2}$ & & \\
\hline 516 & $\mathrm{~B}_{5 \mathrm{~s}}+\mathrm{CO}^{2+}$ & 760 & $\mathrm{~A}_{4}$ & & \\
\hline 523.5 & $\mathrm{~A}_{5 \mathrm{O}^{\prime}}^{2+}$ & 770 & $\mathrm{~B}_{4}-\mathrm{H}_{2} \mathrm{O}$ & & \\
\hline 537.5 & $\mathrm{~B}_{5 \mathrm{O}^{\prime}}^{2+}$ & 788 & $\mathrm{~B}_{4}$ & & \\
\hline 540.5 & {$\left[\mathrm{M}+2 \mathrm{H}-\mathrm{CO}-2 \mathrm{H}_{2} \mathrm{O}-\mathrm{NH}_{3}\right]^{2+}$} & 805 & $\mathrm{C}_{4}^{\prime \prime}$ & & \\
\hline 549 & {$\left[\mathrm{M}+2 \mathrm{H}-\mathrm{CO}-2 \mathrm{H}_{2} \mathrm{O}\right]^{2+}$} & 816 & $\mathrm{~B}_{4}+\mathrm{CO}$ & & \\
\hline 549.5 & {$\left[\mathrm{M}+2 \mathrm{H}-\mathrm{CO}-\mathrm{H}_{2} \mathrm{O}-\mathrm{NH}_{3}\right]^{2+}$} & 833 & $\mathrm{C}_{4}^{\prime \prime}+\mathrm{CO}$ & & \\
\hline
\end{tabular}

1 has been found for all pyoverdins the structure of which was confirmed by NMR, is certainly a weak argument for formulating the incorporation of the branching Lys in the same way for all pyoverdins discussed here. A better argument is the following one: For those pyoverdins where Lys is incorporated into the linear peptide chain by its $\varepsilon$ - rather than by its $\alpha$-amino group, the B-fragment resulting from the cleavage of the next peptide bond is absent or of very low abundance as compared with the other B-fragments (see the discussion in [25]). For the pyoverdins where Lys branches into the cycle this would be the cleavage according to path I in Fig. 6 which for the reversed orientation of Lys should be suppressed. Consequently, daughter ions derived from this species should essentially be missing. For 1 with the correct orientation of Lys, e.g., the ion $\mathrm{B}_{5 \mathrm{~S}}^{2+}$ is the one second in abundance in the spectrum Fig. 4 . For all pyoverdins discussed subsequently the corresponding ion formed by the loss of the amino acid residue after the branching Lys is of high abundance. At least, from the observation that all pyoverdins investigated fragment in an analogous way, it may be concluded that Lys is oriented as in $\mathbf{1}$.

As can be seen from Table 2 (italics) several rearrangement ions of low abundance can be observed. They are not a typical feature of the cyclic part of the molecule and will be discussed in a subsequent publication.

\subsubsection{Pyoverdins of Pseudomonas sp. 96.318}

The crude extract from the bacterial culture contained several pyoverdins differing in the nature of the dicarboxylic acid bound to the chromophore (succinamide, succinic acid, ketoglutaric acid). $[\mathrm{M}+2 \mathrm{H}]^{2+}$ of the pyoverdin with the succinamide side chain (2) was selected for structural analysis. 


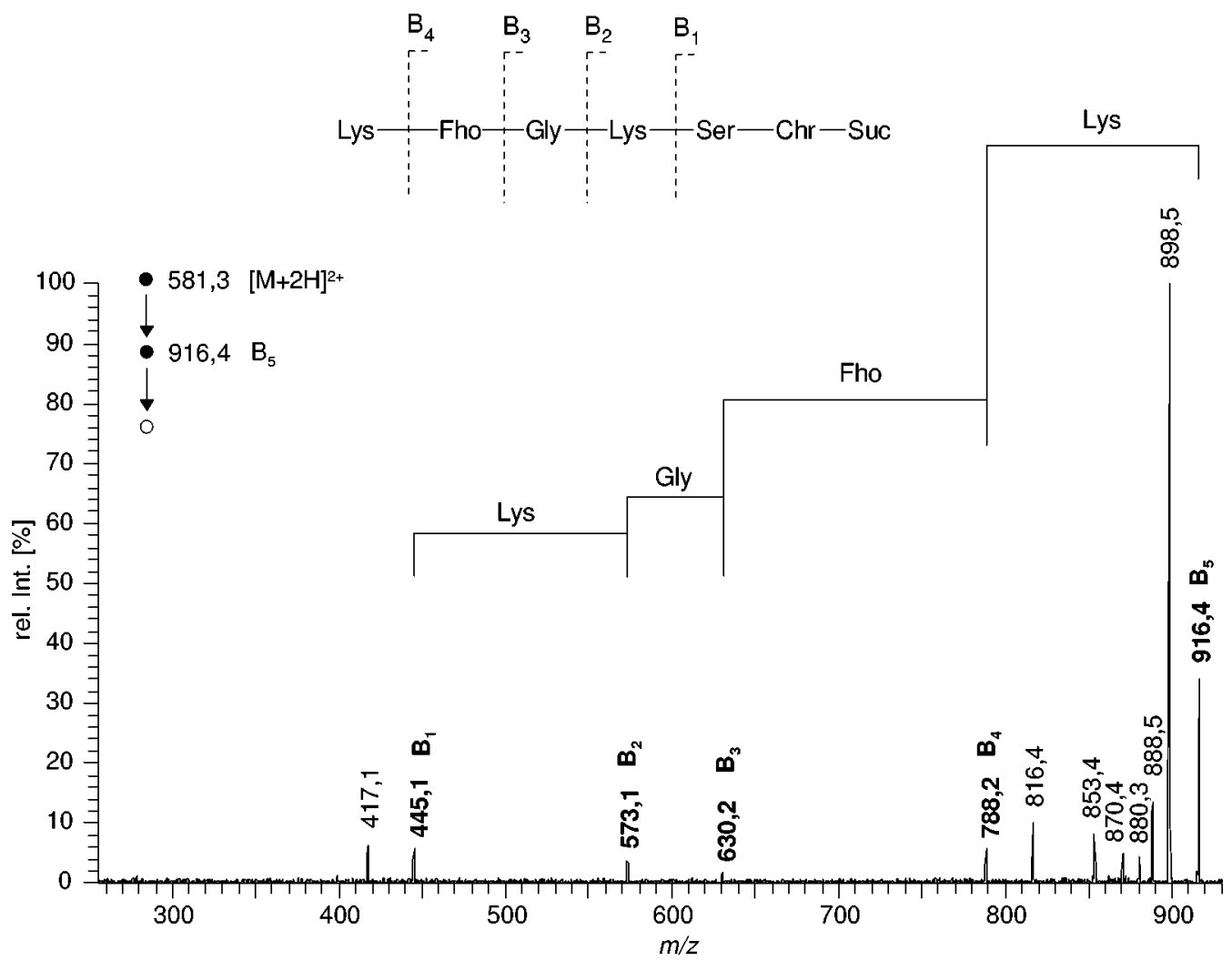

Fig. 5. CA spectrum of the $\mathrm{B}_{5}$-ion obtained from $[\mathrm{M}+2 \mathrm{H}]^{2+}$ (Fig. 4) of $\mathbf{1}$ (sequence relevant ions in bold).

In the octapole CA spectrum again only the sequence relevant ion $\mathrm{A}_{1}(\mathrm{~m} / \mathrm{z} 416)$ can be seen indicating Ser as the first amino acid. CA in the ion trap gives results in complete analogy to $\mathbf{1}$. It yields $\mathrm{B}_{1}$ to $\mathrm{B}_{5}$ and $\mathrm{Y}_{3}^{\prime \prime}$ to $\mathrm{Y}_{7}^{\prime \prime}$. This establishes the sequence of the linear part as Suca-Chr-Ser-Orn-Fho-Ser-Ser. Further $\mathrm{CA}$ of the $\mathrm{B}_{5}$-ion $\left(\mathrm{m} / z\right.$ 990) confirms this result since i.a. the ions $\mathrm{B}_{1}$ to $\mathrm{B}_{3}$ are obtained. As in the case of $\mathbf{1}$ the ion $\mathbf{B}_{6}(\mathrm{~m} / z, 1018)$ indicates that the next amino acid is Lys. Also here $\mathbf{B}_{6}$ stems from an opening of the terminal ring after protonation of the $\varepsilon$-amino group. The presence of $\mathbf{B}_{6 \mathrm{~S}}^{2+}(\mathrm{m} / \mathrm{z} 553)$ and $\mathbf{B}_{6 \mathrm{O}^{\prime}}^{2+}(\mathrm{m} / z$ 588.5) and its congeners confirms the composition of the terminal cycle in the same way as the fragments obtained from $\mathrm{Y}_{3}^{\prime \prime}$ (losses of Fho and Ser, cf. the discussion of $\mathbf{1}$ ). The sequence of the amino acids in the terminal ring can be deduced from the further fragmentation of $\mathrm{A}_{6 \mathrm{O}^{\prime}}^{2+}(\mathrm{m} / \mathrm{z}, 574.5)$ (as described for 1). It follows the structure depicted in Fig. 8.

\subsubsection{Pyoverdins from Pseudomonas marginalis $G 76$}

The extract contained several pyoverdins containing succinamide, succinic acid, Glu and ketoglutaric acid as side chains. $[\mathrm{M}+2 \mathrm{H}]^{2+}$ of the pyoverdin with the ketoglutaric acid side chain $(3)$ was further analyzed. Daughter ions containing the ketoglutaric acid side chain are usually of low abundance since they readily lose $\mathrm{CO}_{2}$ and $\mathrm{H}_{2} \mathrm{O}$ (loss of $62 \mathrm{u}$ ). The resulting ions will be characterized by the symbol $\left(^{\#}\right.$ ).

In the octapole CA spectrum again only the sequence relevant ion $A_{1}^{\#}(m / z 383)$ can be seen indicating Ser as the first amino acid. $C A$ in the ion trap (Table 4) yields $B_{2}$ to $B_{5}$ plus $B_{3}^{\#}$ to $B_{5}^{\#}$ and $Y_{3}^{\prime \prime}$ to $Y_{6}^{\prime \prime}$ together with several A- and C-ions, all accompanied by losses of small neutral molecules. This establishes the sequence of the linear part Kgl-Chr-Ser-Ser-Fho-Ser-Ser. $\mathrm{MS}^{3}$ of $\mathrm{B}_{5}^{\#}$ gives the entire $\mathrm{A}^{\#-}$ and $\mathrm{B}^{\#}$ - 

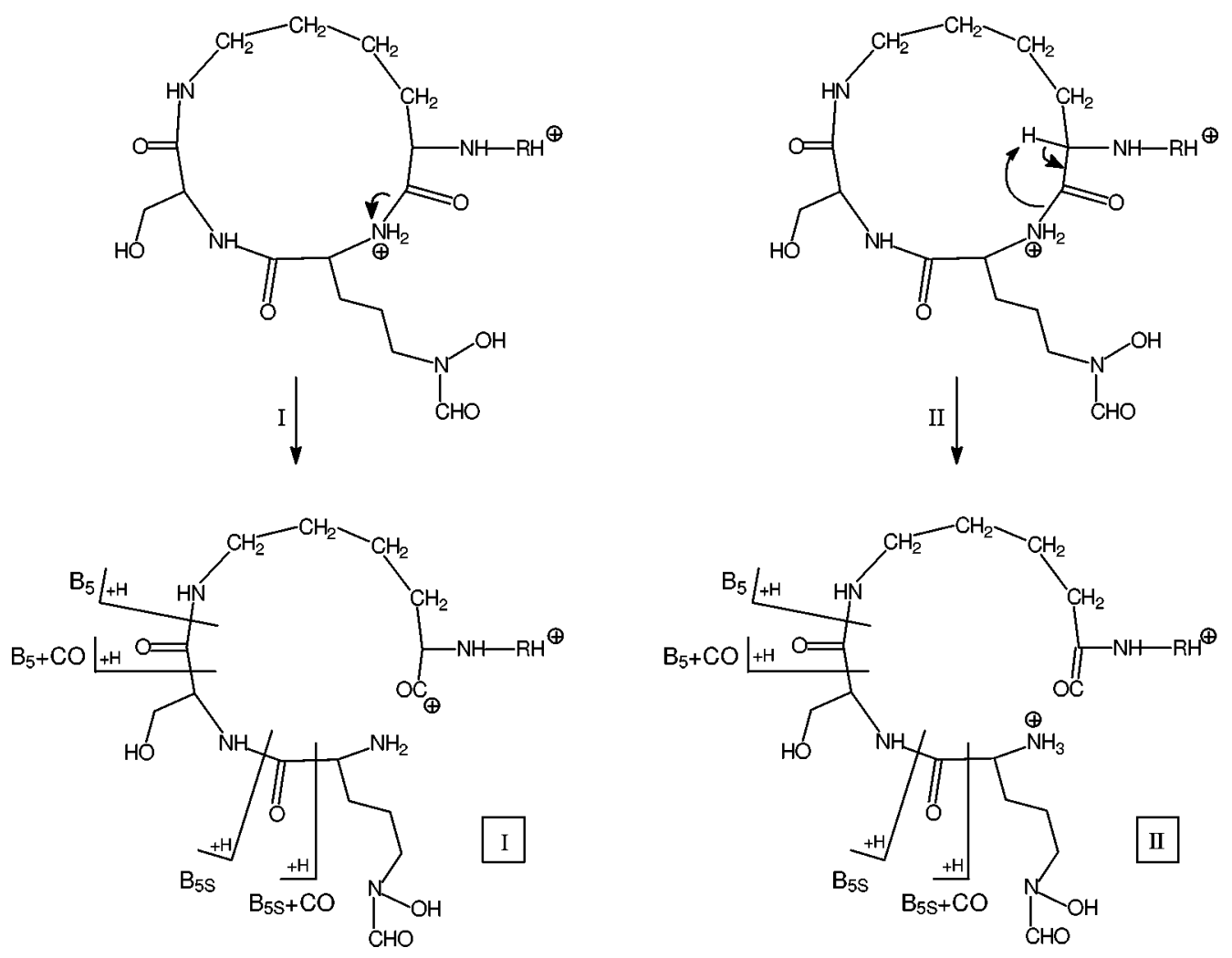

Fig. 6. Fragmentation of the cyclopeptidic part of $\mathbf{1}$ after protonation of the Lys-Fho bond.

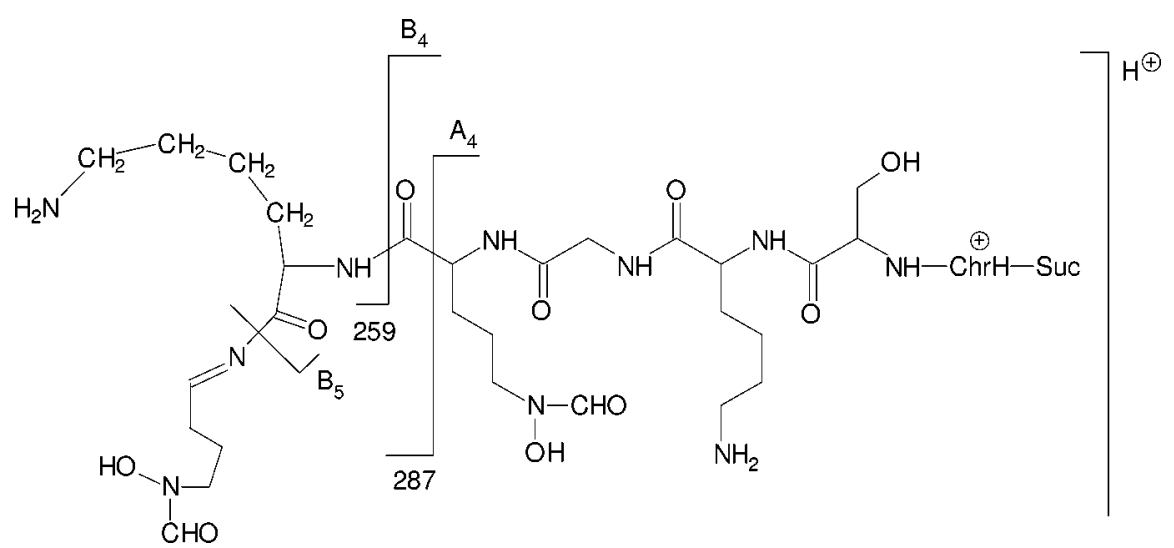

Fig. 7. Fragmentation of the ion $\mathrm{A}_{5 \mathrm{O}^{\prime}}^{2+} \rightarrow \mathrm{B}_{5}^{2+}$ from $\mathbf{1}$.

sequence and thus confirms the assignments. As in the case of $\mathbf{1}$ and $\mathbf{2}$ the ions $\mathbf{B}_{6}$ and $\mathbf{B}_{6}^{\#}(\mathrm{~m} / z 1020$ and 958) indicate that the next amino acid is Lys. Also here they stem from an opening of the terminal ring after protonation of the $\varepsilon$-amino group. The presence of $\mathrm{B}_{6 \mathrm{~S}}^{2+}$ and $\mathrm{B}_{6 \mathrm{O}^{\prime}}^{2+}$ and their congeners as well as the fragments obtained from $Y_{3}^{\prime \prime}$ (losses of Fho and Ser, cf. the discussion of $\mathbf{1}$ ) elucidate the composition of the terminal cycle. The only fragment that would have allowed to determine the sequence of the 
Table 3

Ions observed after $\mathrm{CA}$ of the ion $\mathrm{A}_{5 \mathrm{O}^{\prime}}^{2+}$ from $\mathbf{1}$ (rearrangement products in italic)

\begin{tabular}{llllll}
\hline$m / z$ & Fragments & $m / z$ & Fragments & $m / z$ & Fragments \\
\hline 259 & cf. Fig. 7 & 505.5 & $\mathrm{~A}_{50^{\prime}}-2 \mathrm{H}_{2} \mathrm{O}^{2+}$ & 760 & $\mathrm{~A}_{4}$ \\
287 & cf. Fig. 7 & 509.5 & $\mathrm{~A}_{50^{\prime}}-\mathrm{CO}^{2+}$ & 788 & $\mathrm{~B}_{4}$ \\
449.5 & $\mathrm{~B}_{5}-\mathrm{H}_{2} \mathrm{O}^{2+}$ & 514.5 & $\mathrm{~A}_{50^{\prime}}-\mathrm{H}_{2} \mathrm{O}^{2+}$ & 918 & $A_{4}+$ Fho \\
458.5 & $\mathrm{~B}_{5}^{2+}$ & 515 & $\mathrm{~A}_{5 \mathrm{O}^{\prime}}-\mathrm{NH}_{3}^{2+}$ & & \\
492 & $\mathrm{~A}_{5 \mathrm{O}^{\prime}-\mathrm{H}_{2} \mathrm{O}-\mathrm{CO}^{2+} \mathrm{NH}_{3}^{2+}}$ & 742 & $\mathrm{~A}_{4}-\mathrm{H}_{2} \mathrm{O}$ & & \\
\hline
\end{tabular}

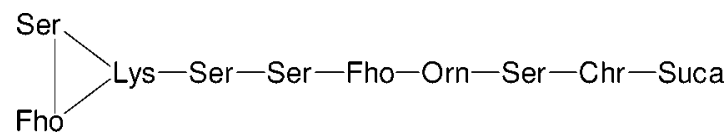

Fig. 8. Structure of the pyoverdin 96.318 (2).

Table 4

Ions observed in the ion trap CA spectrum of $[\mathrm{M}+2 \mathrm{H}]^{2+}$ of $\mathbf{3}$

\begin{tabular}{|c|c|c|c|c|c|}
\hline$m / z$ & Fragments & $m / z$ & Fragments & $\mathrm{m} / \mathrm{z}$ & Fragments \\
\hline 356 & $\mathrm{Y}_{3}^{\prime \prime}-\mathrm{H}_{2} \mathrm{O}$ & 584 & {$\left[\mathrm{M}^{\#}+2 \mathrm{H}-2 \mathrm{H}_{2} \mathrm{O}\right]^{2+}$} & 830 & $\mathrm{~B}_{5}^{\#}$ \\
\hline 374 & $\mathrm{Y}_{3}^{\prime \prime}$ & 588 & {$\left[\mathrm{M}^{\#}+2 \mathrm{H}-\mathrm{CO}\right]^{2+}$} & 847 & $\mathrm{C}_{5}^{\prime \prime \#}$ \\
\hline 425.5 & $\mathrm{Y}_{4}^{\prime \prime}-\mathrm{H}_{2} \mathrm{O}-\mathrm{NH}_{3}$ & 589.5 & $\mathrm{~B}_{6 \mathrm{O}^{\prime}}^{2+}$ & 856 & $\mathrm{~B}_{5}-2 \mathrm{H}_{2} \mathrm{O}$ \\
\hline 443 & $\mathrm{Y}_{4}^{\prime \prime}-\mathrm{H}_{2} \mathrm{O}$ & 593 & {$\left[\mathrm{M}^{\#}+2 \mathrm{H}-\mathrm{H}_{2} \mathrm{O}\right]^{2+}$} & 874 & $\mathrm{~B}_{5}-\mathrm{H}_{2} \mathrm{O}$ \\
\hline 461 & $Y_{4}^{\prime \prime}$ & 602 & {$\left[\mathrm{M}^{\#}+2 \mathrm{H}\right]^{2+}$} & 892 & $\mathrm{~B}_{5}$ \\
\hline 505 & $\mathrm{~B}_{6 \mathrm{~S}}^{\#}-2 \mathrm{H}_{2} \mathrm{O}^{2+}$ & 606 & {$\left[\mathrm{M}+2 \mathrm{H}-3 \mathrm{H}_{2} \mathrm{O}\right]^{2+}$} & 909 & $\mathrm{C}_{5}^{\prime \prime}$ \\
\hline 514 & $\mathrm{~B}_{6 \mathrm{~S}}^{\#}-\mathrm{H}_{2} \mathrm{O}^{2+}$ & 610 & {$\left[\mathrm{M}+2 \mathrm{H}-\mathrm{CO}-\mathrm{H}_{2} \mathrm{O}\right]^{2+}$} & 958 & $\mathrm{~B}_{6}^{\#}$ \\
\hline 519 & $\mathrm{C}_{6}^{\prime \prime 2+}$ & 615 & {$\left[\mathrm{M}+2 \mathrm{H}-2 \mathrm{H}_{2} \mathrm{O}\right]^{2+}$} & 1002 & $\mathrm{~B}_{6}-\mathrm{H}_{2} \mathrm{O}$ \\
\hline 523 & $\mathrm{~B}_{6 \mathrm{~S}}^{\# 2+}$ & 619 & {$[\mathrm{M}+2 \mathrm{H}-\mathrm{CO}]^{2+}$} & 1020 & $\mathrm{~B}_{6}$ \\
\hline 531.5 & $\mathrm{C}_{6 \mathrm{~S}}^{\prime \prime} \# 2+$ & 624 & {$\left[\mathrm{M}+2 \mathrm{H}-\mathrm{H}_{2} \mathrm{O}\right]^{2+}$} & 1037 & $\mathrm{C}_{6}^{\prime \prime}$ \\
\hline 536 & $\mathrm{~B}_{6 \mathrm{~S}}-2 \mathrm{H}_{2} \mathrm{O}^{2+}$ & 656 & $\mathrm{~B}_{3}^{\#}$ & 1045 & $\mathrm{~B}_{6 \mathrm{~S}}^{\#}$ \\
\hline 545 & $\mathrm{~B}_{6 \mathrm{~S}}-\mathrm{H}_{2} \mathrm{O}^{2+}$ & 672 & $\mathrm{~A}_{3}-\mathrm{H}_{2} \mathrm{O}$ & 1062 & $\mathrm{C}_{6 \mathrm{~S}}^{\prime \prime \#}$ \\
\hline 548 & $\mathrm{Y}_{5}^{\prime \prime}$ & 690 & $\mathrm{~A}_{3}$ & 1079 & $\mathrm{~A}_{6 \mathrm{~S}}$ \\
\hline 550 & $\mathrm{~B}_{6 \mathrm{~S}}+\mathrm{CO}-2 \mathrm{H}_{2} \mathrm{O}^{2+}$ & 700 & $\mathrm{~B}_{3}-\mathrm{H}_{2} \mathrm{O}$ & 1099 & $\mathrm{~B}_{6 \mathrm{~S}}+\mathrm{CO}-2 \mathrm{H}_{2} \mathrm{O}$ \\
\hline 554 & $\mathrm{~B}_{6 \mathrm{~S}}^{2+}$ & 706 & $\mathrm{Y}_{6}^{\prime \prime}$ & 1106 & $\mathrm{C}_{6 \mathrm{~S}}^{\prime \prime}-\mathrm{H}_{2} \mathrm{O}$ \\
\hline 559 & $\mathrm{~B}_{6 \mathrm{~S}}+\mathrm{CO}-\mathrm{H}_{2} \mathrm{O}^{2+}$ & 718 & $\mathrm{~B}_{3}$ & 1107 & $\mathrm{~B}_{6 \mathrm{~S}}$ \\
\hline 560 & $\mathrm{~B}_{2}$ & 743 & $\mathrm{~B}_{4}^{\#}$ & 1117 & $\mathrm{~B}_{6 \mathrm{~S}}+\mathrm{CO}-\mathrm{H}_{2} \mathrm{O}$ \\
\hline 562.5 & $\mathrm{C}_{6 \mathrm{~S}}^{\prime \prime 2+}$ & 787 & $\mathrm{~B}_{4}-\mathrm{H}_{2} \mathrm{O}$ & 1124 & $\mathrm{C}_{6 \mathrm{~S}}^{\prime \prime}$ \\
\hline 579 & {$\left[\mathrm{M}^{\#}+2 \mathrm{H}-\mathrm{CO}-\mathrm{H}_{2} \mathrm{O}\right]^{2+}$} & 805 & $\mathrm{~B}_{4}$ & 1135 & $\mathrm{~B}_{6 \mathrm{~S}}+\mathrm{CO}$ \\
\hline 580.5 & $\mathrm{~B}_{6 \mathrm{O}^{\prime}}-\mathrm{H}_{2} \mathrm{O}^{2+}$ & 822 & $\mathrm{C}_{4}^{\prime \prime}$ & & \\
\hline
\end{tabular}

amino acids in the cycle is $\mathrm{C}_{6 \mathrm{~S}}^{\prime \prime 2+}$, but upon $\mathrm{CA}$ it only gave $\mathrm{C}_{6 \mathrm{~S}}^{\prime \prime \prime 2+2+}$ whose abundance was too low for further investigation. Hence only the identical fragmentation pattern upon $\mathrm{CA}$ of $\mathrm{Y}_{3}^{\prime \prime}$ from 1, 2 and from $\mathbf{3}$ suggests that the amino acid sequence is the same in all three instances. Thus, the structure depicted in Fig. 9 can be ascribed to 3 . 


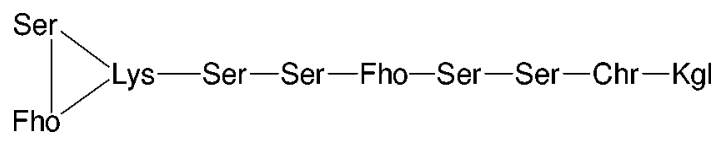

Fig. 9. Structure of the pyoverdin G76 (3).

\subsection{Pyoverdins with a cyclotetrapeptidic C-terminal part}

\subsubsection{Pyoverdin from Pseudomonas sp. 95.275}

First the results of a pyoverdin with known structure (4) ([26]) will be reported. The facile loss of $\mathrm{H}_{2} \mathrm{O}$ $+\mathrm{CO}_{2}$ from ketoglutaric acid side chain yielding ${ }^{\#}$-ions has been mentioned before. In the octapole CA spectrum of $[\mathrm{M}+2 \mathrm{H}]^{2+}$ only $\mathrm{A}_{1}^{\#}(\mathrm{~m} / \mathrm{z}, 383)$ is observed with high abundance corresponding to Ser as the first amino acid.

In the ion trap CA spectrum (Fig. 10 and Table 5) of $\left[\mathbf{M}^{\#}+2 \mathrm{H}\right]^{2+}\left(\mathrm{m} / z\right.$ 666) the ions $\mathbf{B}_{4}^{\#}$ and $\mathbf{B}_{5}^{\#}$ can be seen with high, $\mathbf{B}_{6}^{\#}(\mathrm{~m} / z$ 958) with somewhat lower abundance. Further CA fragmentation of $\mathrm{B}_{6}^{\#}$ confirms the sequence. No ion can be found which would correspond to the loss of an amino acid from the C-terminus. The only loss from $\left[\mathrm{M}^{\#}+2 \mathrm{H}\right]^{2+}$ amounting to an amino acid residue corresponds to NHCHRCO of Lys. This points towards a cyclic structure where a second Lys is part of the cycle. Correspondingly ions of high abundance can be discerned which contain amino acid residues connected with the $\mathrm{C}$-terminal branching amino acid of $\mathbf{B}_{6}^{\#}$ (the first Lys in the molecule): $\mathbf{B}_{6 \mathrm{~S}}^{\#}\left(\mathrm{~m} / z\right.$ 1045) and $\mathbf{B}_{6 \mathrm{O}^{\prime}}^{\#}$ $\left(\mathrm{m} / z\right.$ 1116) point towards the two amino acids connected with Lys and $\mathbf{B}_{6 \mathrm{O}^{\prime} \mathrm{S}}(\mathrm{m} / \mathrm{z}$ 1203) completes the cycle. Further fragments as depicted in Fig. 11 offer a confirmation. The $\mathrm{Y}_{4}^{\prime \prime}$-ion $(\mathrm{m} / \mathrm{z}, 502)$ upon CA does not give much additional information as the only abundant ion amounts to the loss of Lys. More important is the observation of $\mathrm{A}_{6 \mathrm{O}^{\prime} \mathrm{S}}^{\# 2+}$ which upon $\mathrm{CA}$ loses the Fho residue yielding $\mathrm{B}_{6 \mathrm{~S}}^{\# 2+}$ in analogy to the fragmentation of $\mathrm{A}_{5 \mathrm{O}^{\prime}}^{2+}$ in the case of $\mathbf{1}$ (see Fig. 7). Thus the sequence of the amino acids in the cycle can be determined (Fig. 11).

\subsubsection{Pyoverdins from Pseudomonas sp. 96.312}

The culture extract of Pseudomonas sp. 96.312 contains pyoverdins with the side chains succinamide, succinic acid, ketoglutaric acid and Glu. The first of these (5) was selected for structural studies. Its peptide part differs from that of $\mathbf{4}$ only insofar that the two Ser between Fho and Lys are missing. Consequently, it shows an analogous fragmentation behavior. The octapole CA spectrum demonstrates that Ser is the first amino acid. The B-series in the ion trap CA spectrum of $[\mathrm{M}+2 \mathrm{H}]^{2+}$ is confirmed by further $\mathrm{CA}$ of $\mathrm{B}_{3}$ resulting in the loss of Fho and Ser. From the identical cyclic part the characteristic ions discussed for 4 can be seen. $\mathrm{Y}_{4}^{\prime \prime}$ comprising the cyclus shows essentially only the loss of Lys. From $\mathrm{A}_{4 \mathrm{O}^{\prime} \mathrm{S}}^{2+}$ $\left(\mathrm{m} / \mathrm{z}\right.$ 517.5) giving $\mathrm{B}_{4 \mathrm{~S}}^{2+}$ it follows the sequence of amino acids in the cycle (Fig. 12).

\subsubsection{Pyoverdins from Pseudomonas rhodesiae L25}

Also here pyoverdins with different side chains (succinamide, succinic acid, ketoglutaric acid) were present in the extract. The one with ketoglutaric acid (6) (regarding the " -ions see above) was selected for further investigation. Of interest is the cycle which contains two Ser instead of one Lys and one Ser. The octapole CA spectrum again allows to identify Ser as the first amino acid. The linear part of the peptide chain can be deduced from the $\mathrm{B}$ - and $\mathrm{Y}^{\prime \prime}$-series confirmed by $\mathrm{CA}$ of the $\mathrm{C}_{6}^{\#-}$-ion. $\mathrm{B}_{7 \mathrm{~S}}^{\# 2+}\left(\mathrm{m} / z\right.$ 572), $\mathrm{B}_{7 \mathrm{O}^{\prime}}^{\# 2+}$ $(\mathrm{m} / \mathrm{z} 607.5), \mathbf{B}_{7 \mathrm{SS}}^{\# 2+}(\mathrm{m} / \mathrm{z} 615.5)$ and $\mathbf{B}_{7 \mathrm{O}^{\prime} \mathrm{S}}^{\# 2+}(\mathrm{m} / \mathrm{z} 651)$ allow to deduce the structure of the cyclic part. A $\mathbf{Y}_{4}^{\prime \prime}$ is missing, also any ion which would allow to differentiate between sequence and retro-sequence. The placement of Fho next to Lys follows only the general pattern (Fig. 13). 
- $697,3[\mathrm{M}+2 \mathrm{H}]^{2+}$

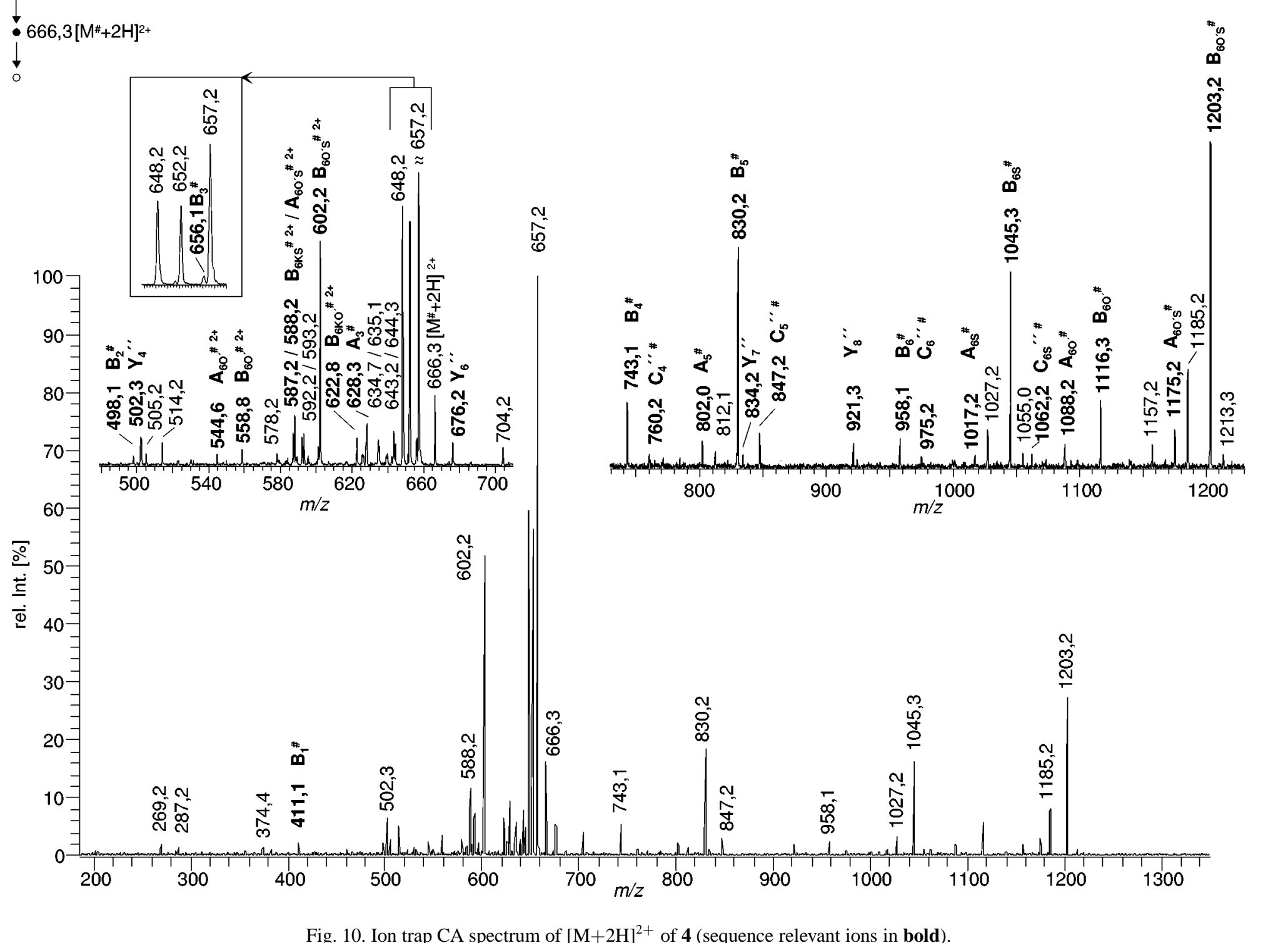


Table 5

Ions observed in the ion trap CA spectrum of $[\mathrm{M}+2 \mathrm{H}]^{2+}$ of $\mathbf{4}$ (rearrangement products in italic)

\begin{tabular}{|c|c|c|c|c|c|}
\hline $\mathrm{m} / \mathrm{z}$ & Fragments & $m / z$ & Fragments & $\mathrm{m} / \mathrm{z}$ & Fragments \\
\hline 269 & $\mathrm{Y}_{4}^{\prime \prime}$ Lys-Ser- $\mathrm{H}_{2} \mathrm{O}$ & 628 & $\mathrm{~A}_{3}^{\#}$ & 847 & $\mathrm{C}_{5}^{\prime \prime \#}$ \\
\hline 287 & $\mathrm{Y}_{4}^{\prime \prime}$ Lys-Ser & 634.5 & {$\left[\mathrm{M}^{\#}+2 \mathrm{H}-\mathrm{CO}-\mathrm{H}_{2} \mathrm{O}-\mathrm{NH}_{3}\right]^{2+}$} & 921 & $\mathrm{Y}_{8}^{\prime \prime}$ \\
\hline 374 & $\mathrm{Y}_{4}^{\prime \prime}$-Lys & 635 & {$\left[\mathrm{M}^{\#}+2 \mathrm{H}-\mathrm{CO}_{2}-\mathrm{H}_{2} \mathrm{O}\right]^{2+}$} & 958 & $\mathrm{~B}_{6}^{\#}$ \\
\hline 411 & $\mathrm{~B}_{1}^{\#}$ & 643 & {$\left[\mathrm{M}^{\#}+2 \mathrm{H}-\mathrm{CO}-\mathrm{H}_{2} \mathrm{O}\right]^{2+}$} & 975 & $\mathrm{C}_{6}^{\prime \prime \#}$ \\
\hline 498 & $\mathrm{~B}_{2}^{\#}$ & 644 & {$\left[\mathrm{M}^{\#}+2 \mathrm{H}-\mathrm{CO}_{2}\right]^{2+}$} & 1017 & $\mathrm{~A}_{6 \mathrm{~S}}^{\#}$ \\
\hline 502 & $\mathrm{Y}_{4}^{\prime \prime}$ & 648 & {$\left[\mathrm{M}^{\#}+2 \mathrm{H}-2 \mathrm{H}_{2} \mathrm{O}\right]^{2+}$} & 1027 & $\mathrm{~B}_{6 \mathrm{~S}}^{\#}-\mathrm{H}_{2} \mathrm{O}$ \\
\hline 505 & $\mathrm{~B}_{6 \mathrm{~S}}^{\#}-2 \mathrm{H}_{2} \mathrm{O}^{2+}$ & 652 & {$\left[\mathrm{M}^{\#}+2 \mathrm{H}-\mathrm{CO}\right]^{2+}$} & 1045 & $\mathrm{~B}_{6 \mathrm{~S}}^{\#}$ \\
\hline 514 & $\mathrm{~B}_{6 \mathrm{~S}}^{\#}-\mathrm{H}_{2} \mathrm{O}^{2+}$ & 656 & $\mathrm{~B}_{3}^{\#}$ & 1055 & $\mathrm{~B}_{6 \mathrm{~S}}^{\#}+\mathrm{CO}-\mathrm{H}_{2} \mathrm{O}$ \\
\hline 544.5 & $\mathrm{~A}_{6 \mathrm{O}^{\prime}}^{\# 2+}$ & 657 & {$\left[\mathrm{M}^{\#}+2 \mathrm{H}-\mathrm{H}_{2} \mathrm{O}\right]^{2+}$} & 1062 & $\mathrm{C}_{6 \mathrm{~S}}^{\prime \prime \#}$ \\
\hline 558.5 & $\mathrm{~B}_{6 \mathrm{O}^{\prime}}^{\# 2+}$ & 676 & $\mathrm{Y}_{6}^{\prime \prime}$ & 1088 & $\mathrm{~A}_{6 \mathrm{O}^{\prime}}^{\#}$ \\
\hline 578 & $\mathrm{~B}_{6 \mathrm{SK}}^{\#}-\mathrm{H}_{2} \mathrm{O}^{2+}$ & 704 & $Y_{6}^{\prime \prime}+C O$ & 1116 & $\mathrm{~B}_{6 \mathrm{O}^{\prime}}^{\#}$ \\
\hline 587 & $\mathrm{~B}_{6 \mathrm{SK}}^{\# 2+}$ & 743 & $\mathrm{~B}_{4}^{\#}$ & 1157 & $\mathrm{~A}_{6 \mathrm{O}^{\prime} \mathrm{S}}^{\#}-\mathrm{H}_{2} \mathrm{O}$ \\
\hline 588 & $\mathrm{~A}_{6 \mathrm{O}^{\prime} \mathrm{S}}^{\# 2+}$ & 760 & $\mathrm{C}_{4}^{\prime \prime \#}$ & 1175 & $\mathrm{~A}_{6 \mathrm{O}^{\prime} \mathrm{S}}^{\#}$ \\
\hline 592 & $\mathrm{~B}_{6 \mathrm{SK}}^{\mathrm{H2}+}+\mathrm{CO}-\mathrm{H}_{2} \mathrm{O}$ & 802 & $\mathrm{~A}_{5}^{\#}$ & 1185 & $\mathrm{~B}_{6 \mathrm{O}^{\prime} \mathrm{S}}^{\#}-\mathrm{H}_{2} \mathrm{O}$ \\
\hline 593 & $\mathrm{~B}_{6 \mathrm{O}^{\prime} \mathrm{S}^{\prime}}^{\#}-\mathrm{H}_{2} \mathrm{O}^{2+}$ & 812 & $\mathrm{~B}_{5}^{\#}-\mathrm{H}_{2} \mathrm{O}$ & 1203 & $\mathrm{~B}_{6 \mathrm{O}^{\prime} \mathrm{S}}^{\#}$ \\
\hline 602 & $\mathrm{~B}_{6 \mathrm{O}^{\prime} \mathrm{S}}^{\# 2+}$ & 830 & $\mathrm{~B}_{5}^{\#}$ & 1213 & $\mathrm{~B}_{6 \mathrm{O}^{\prime} \mathrm{S}}^{\#}+\mathrm{CO}-\mathrm{H}_{2} \mathrm{O}$ \\
\hline 622.5 & $\mathrm{~B}_{6 \mathrm{KO}^{\prime}}^{\# 2+}$ & 834 & $\mathrm{Y}_{7}^{\prime \prime}$ & & \\
\hline
\end{tabular}

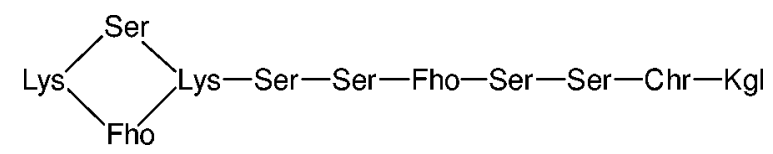

Fig. 11. Structure of the pyoverdin 95.275 (4).

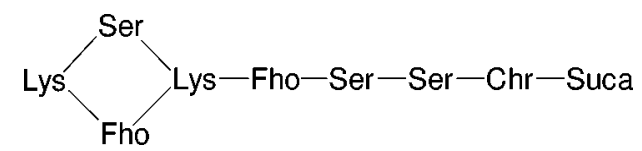

Fig. 12. Structure of the pyoverdin 96.312 (5).

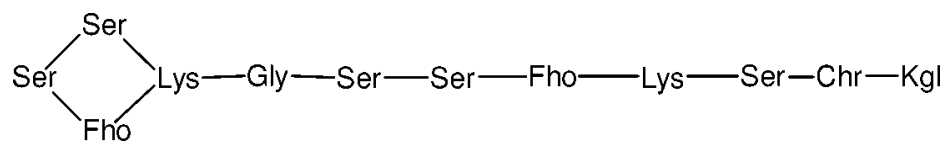

Fig. 13. Structure of the pyoverdin L25 (6).

\subsubsection{Pyoverdins from Pseudomonas fluorescens D47}

In $\mathbf{4}$ and 5 the second amino acid after the branching Lys was a basic Lys, in $\mathbf{6}$ a neutral one. Here it will be the acidic Glu. The side chains were the same as before and succinamide (7) was selected. The octapol CA spectrum establishes Ser as the first amino acid. In ion trap CA spectrum of $[\mathrm{M}+2 \mathrm{H}]^{2+}$ the series of B-ions including the branching Lys and $\mathrm{Y}_{4}^{\prime \prime}\left(\mathrm{m} / z\right.$ 503, cycle) to $\mathrm{Y}_{6}^{\prime \prime}$ can be seen, further CA of $\mathrm{B}_{3}$ indicates the loss of Fho and Orn, that of $\mathrm{Y}_{5}^{\prime \prime}$ that of Fho. The structure of the cycle follows from the ions $\mathrm{B}_{4 \mathrm{~S}}\left(\mathrm{~m} / \mathrm{z}\right.$ 931), $\mathrm{B}_{4 \mathrm{O}^{\prime}}(\mathrm{m} / \mathrm{z} 1002)$ and $\mathrm{B}_{4 \mathrm{SE}}(\mathrm{m} / \mathrm{z} 1060)$, the sequence from $\mathrm{A}_{4 \mathrm{O}^{\prime}}^{2+}(\mathrm{m} / \mathrm{z} 488.5)$ giving upon $\mathrm{CA} \mathrm{B}_{4}^{2+}$ (Fig. 14). 


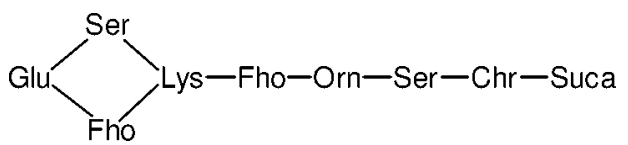

Fig. 14. Structure of the pyoverdin D47 (7).

\section{Conclusion}

If a pure sample is available, the nature of the side chain does not play an important role for structural studies. If, however, several pyoverdins differing in their side chain are present in a culture extract, from the pairs differing by $1 \mathrm{u}$ in mass (succinamide/succinic acid, malamide/malic acid, ketoglutaric acid/Glu) the lower one in mass has to be selected. Otherwise the ${ }^{13} \mathrm{C}$-satellite of the ion of lower mass would coincide with the one one mass unit higher and the fragmentation patterns of the two species would be superimposed. 2-Ketoglutaric acid is less favorable since due to the facile loss of $\mathrm{H}_{2} \mathrm{O}+\mathrm{CO}_{2}$ two series of ions are obtained. The nature of the side chain can be deduced from the characteristic mass differences of the six varieties (see Introduction) since usually several of them co-occur. The presence of succinamide and of ketoglutaric acid discussed in this publication can be confirmed by abundant chromophore fragments in the octapole CA spectra. After loss of the entire peptide chain by a retroDiels-Alder (RDA) mechanism [27] (Fig. 15) the side chain is lost giving an ion at $m / z, 204$ (a), that is abundant for succinic acid or succinamide. In the case of ketoglutaric acid the main fragmentation reaction is the elimination of $\mathrm{H}_{2} \mathrm{O}+\mathrm{CO}_{2}(\mathbf{b}, \mathrm{m} / z$ 270) (Fig. 16). The characteristics for malamide and Glu will be discussed in a review under preparation [1].

$\mathrm{CA}$ of $[\mathrm{M}+\mathrm{H}]^{+}$or $[\mathrm{M}+2 \mathrm{H}]^{2+}$ in the octapole region yields an abundant $\mathrm{A}_{1}$-ion if Ser is the first amino acid in the peptide chain, as it is the case for all examples discussed above. $\mathrm{CA}$ of $[\mathrm{M}+\mathrm{H}]^{+}$in the ion trap shows the sequence specific singly charged ions of the linear part of the peptide chain. At lower collision energies mainly B-ions will be found, at higher energies also A- and $\mathrm{C}^{\prime \prime}$-ions accompanied by losses of various small neutral particles $\left(\mathrm{CO}, \mathrm{H}_{2} \mathrm{O}, \mathrm{NH}_{3}\right)$. Since the proton of the $[\mathrm{M}+\mathrm{H}]^{+}$ion is preferentially located in the chromophore, essentially no $\mathrm{Y}^{\prime \prime}$-ions are observed unless basic amino acids (especially Arg) are present in the chain. In case there are doubts regarding the assignment of any ion, it can be selected in the ion trap and fragmented by $\mathrm{CA}\left(\mathrm{MS}^{n}\right)$. The main advantage of the investigation of singly charged ions is that their fragments are also singly charged while from $[\mathrm{M}+2 \mathrm{H}]^{2+}$ both singly and doubly charged ions are obtained. Information except for its mass ( $\mathrm{M}$ minus the B-ion of highest mass) can, however not be gained regarding the cyclic part of the peptide chain.

While the fragment ions from $[\mathrm{M}+\mathrm{H}]^{+}$are essentially formed by charge-remote processes in $[\mathrm{M}+2 \mathrm{H}]^{2+}$ one of the protons can be located at the various amide bonds. This weakens the respective bond and facilitates its cleavage. From the linear part B- and $\mathrm{Y}^{\prime \prime}$-ions will be obtained giving the same information as had been obtained from $[\mathrm{M}+\mathrm{H}]^{+}$. Protonation of amide bonds in the ring results in ring opening and $\mathrm{CO}-\mathrm{CHR}-\mathrm{NH}$ units are lost. In this way fragments are obtained which comprise the connecting Lys and one or more of the amino acid residues attached to it. In this way at least for tri- and tetra-cyclopeptidic compounds the ring can be reconstructed. The type of the amino acid present (neutral, basic or acidic) is of no importance. A distinction between sequence and retro-sequence (e.g., Lys-A-B-C or Lys-C-B-A) is possible provided sufficiently abundant characteristic A- or C"-ions can be fragmented. In which way Lys linking the linear with the cyclic unit is built into the peptide part ( $\alpha$ $\mathrm{NH}$ in the chain and $\varepsilon-\mathrm{NH}$ in the cycle as depicted in $\mathbf{1}$ or vice versa) can only be deduced from the fact that specific ions stemming from the cyclic part are of high abundance (see discussion of pyoverdin $\mathbf{1}$ ). 


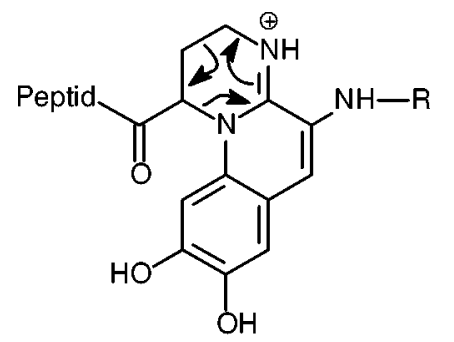<smiles>CCCOC(=O)CC</smiles><smiles>C=Nc1nc2cc(O)c(O)cc2cc1NP</smiles>

$$
\begin{array}{ll}
\mathrm{R}=\mathrm{CO}-\mathrm{CH}_{2}-\mathrm{CH}_{2}-\mathrm{CONH} \mathrm{H}_{2} & \text { Suca } \\
\mathrm{R}=\mathrm{CO}-\mathrm{CH}_{2}-\mathrm{CH}_{2}-\mathrm{CO}-\mathrm{COOH} & \mathrm{Kgl}
\end{array}
$$

Fig. 15. RDA-fragmentation.<smiles>C=[N+]c1nc2cc(O)c(O)cc2cc1NC(=O)CCC(=O)C(=O)O</smiles><smiles>C=Nc1nc2cc(O)c(O)cc2cc1[N+]1=CCC(=O)O1</smiles><smiles>C=[N+]c1nc2cc(O)c(O)cc2cc1NC(=O)CCC(=O)O</smiles><smiles>C=[NH+]c1nc2cc(O)c(O)cc2cc1N</smiles>

Fig. 16. RDA-fragments after fragmentation of the side chain.

The examples presented here demonstrate that an ESI-MS-CA analysis of pyoverdins also with cyclic substructures is possible. In this way known representatives can be identified quickly and for new ones structures can be suggested. Obviously, nothing can be said about the D/L-configuration of the amino acids.

\section{Acknowledgement}

We wish to thank Dr. J.-M. Meyer, University of Strasbourg, for providing the culture extracts of several bacterial strains whose pyoverdins were discussed in this publication. The complete structure elucidation of new pyoverdins will be reported elsewhere. 


\section{References}

[1] R. Fuchs and H. Budzikiewicz, Structural studies of pyoverdins by mass spectrometry, Curr. Org. Chem. (2001), submitted.

[2] H. Budzikiewicz, Siderophores from fluorescent Pseudomonas, in: Studies in Natural Products Chemistry, Atta-urRahman, ed., Vol. 19, Elsevier, Amsterdam, 1997, pp. 793-835.

[3] S. Kilz, Ch. Lenz, R. Fuchs and H. Budzikiewicz, A fast screening method for the identification of siderophores from fluorescent Pseudomonas spp. by liquid chromatography/electrospray mass spectrometry, J. Mass Spectrom. 34 (1999), 281-290.

[4] H. Georgias, K. Taraz, H. Budzikiewicz, V. Geoffroy and J.-M. Meyer, The structure of the pyoverdin from Pseudomonas fluorescens 1.3. Structural and biological relationships of pyoverdins from different strains, Z. Naturforsch. 54c (1999), 301-308.

[5] C. Amann, K. Taraz, H. Budzikiewicz and J.-M. Meyer, The siderophores of Pseudomonas fluorescens 18.1 and the importance of cyclopeptidic substructures for the recognition at the cell surface, Z. Naturforsch. 55c (2000), 671-680.

[6] M. Weber, K. Taraz, H. Budzikiewicz and J.-M. Meyer, The structure of a pyoverdine from Pseudomonas sp. CFML 96.188 and its relation to other pyoverdines with a cyclic C-terminus, Biometals (2001), submitted.

[7] W. Voßen, R. Fuchs, K. Taraz and H. Budzikiewicz, Can the peptide chain of a pyoverdin be bound by an ester bond to the chromophore? - The old problem of pseudobactin 7SR1, Z. Naturforsch. 55c (2000), 153-164.

[8] K. Biemann and S.A. Martin, Mass spectrometric determination of the amino acid sequence of peptides and proteins, Mass Spectrom. Rev. 6 (2000), 1-76.

[9] P. Roepstorff and J. Fohlman, Proposal of a common nomenclature for sequence ions in mass spectra of peptides, Biomed. Mass Spectrom. 11 (1984), 601.

[10] K. Eckart, Mass spectrometry of cyclic peptides, Mass Spectrom. Rev. 13 (1994), 23-55.

[11] L.C.M. Ngoka and M.L. Gross, Multistep tandem mass spectrometry for sequencing cyclic peptides in an ion-trap mass spectrometer. J. Am. Soc. Mass Spectrom. 10 (1999), 732-746.

[12] U. Hohlneicher, R. Hartmann, K. Taraz and H. Budzikiewicz, Pyoverdin, ferribactin, azotobactin - a new triade of siderophores from Pseudomonas chlororaphis and its relation to Pseudomonas fluorescens ATCC 13525, Z. Naturforsch. 50c (1995), 337-344.

[13] U. Hohlneicher, Über Struktur und Biosynthese der Siderophore von Pseudomonas fluorescens ATCC 13525 und Pseudomonas chlororaphis ATCC 9446, Dissertation Universität zu Köln, 1993.

[14] M.M. Siegel, J. Huang, B. Lin, R. Tsao and C.G. Edmonds, Structures of bacitracin and isolated congeners: sequencing of cyclic peptides with blocked linear side chains by electrospray ionization mass spectrometry, Biol. Mass Spectrom. 23 (1994), 186-204.

[15] Á. Somogyi, V.H. Wysocki and I. Mayer, The effect of protonation site on bond strengths in simple peptides: application of $a b$ initio and modified neglect of differential overlap bond orders and modified neglect of differential overlap energy partitioning, J. Am. Chem. Soc. 5 (1994), 704-717.

[16] A.R. Dongré, J.L. Jones, Á. Somogyi and V.H. Wysocki, Influence of peptide composition, gas-phase basicity, and chemical modification on fragmentation efficiency: evidence for the mobile proton model, J. Am. Chem. Soc. 118 (1996), $8365-8374$

[17] A.G. Harrison and T. Yalcin, Proton mobility in protonated amono acids and peptides, Int. J. Mass Spectrom. Ion Proc. 165/166, (1997), 339-347.

[18] K.A. Cox, S.J. Gaskell, M. Morris and A. Whiting, Role of the site of protonation in the low-energy decompositions of gas-phase peptide ions, J. Am. Soc. Mass Spectrom. 7 (1996), 522-531.

[19] P.-C. Liao, Z.-H. Huand and J. Allison, Charge remote fragmentation of peptides following attachment of a fixed positive charge: a matrix-assisted laser desorption/ionization postsource decay study, J. Am. Soc. Mass Spectrom. 8 (1997), 501509.

[20] K.D.W. Roth, Z.-H. Huang, N. Sadapogan and J.T. Watson, Charge derivatization of peptides for analysis by mass spectrometry, Mass Spectrom. Rev. 17 (1998), 255-274.

[21] X.-J. Tang, P. Thibault and R.K. Boyd, Fragmentation reactions of multiprotonated peptides and implications for sequencing by tandem mass spectrometry with low-energy collision-induced dissociation, Anal. Chem. 65 (1993), 2824-2834.

[22] T. Yalcin, C. Khouw, I.G. Csizmadia, M.R. Peterson and A.G. Harrison, Why are B ions stable species in peptide spectra?, J. Am. Soc. Mass Spectrom. 6 (1995), 1164-1174.

[23] M.J. Nold, C. Wesdemiotis, T. Yalcin and A.G. Harrison, Amide bond dissociation in protonated peptides. Structures of the N-terminal ionic and neutral fragments, Int. J. Mass Spectrom. Ion Proc. 164 (1997), 137-153.

[24] P.T.M. Kenny, K. Nomoto and R. Orlando, Fragmentation studies of peptides: the formation of Y ions, Rapid Commun. Mass Spectrom. 6 (1992), 95-97.

[25] H. Budzikiewicz, D. Uría Fernandez, R. Fuchs, R. Michalke, K. Taraz and C. Rungiviriachai, Pyoverdins with a Lys $\varepsilon$-amino link in the peptide chain?, Z. Naturforsch. 54c (1999), 1021-1026. 
[26] R. Sultana, B.S. Siddiqui, R. Fuchs, H. Schmickler, K. Schlegel, H. Budzikiewicz and J.-M. Meyer, A pyoverdin from Pseudomonas sp. CFML 95-275, Z. Naturforsch. 55c (2000), in press.

[27] J. Michels, H. Benoni, G. Briskot, J. Lex, H. Schmickler, K. Taraz, H. Budzikiewicz, H. Korth and G. Pulverer, Isolierung und spektroskopische Charakterisierung des Pyoverdin-Chromophors sowie seines 5-Hydroxy-Analogen, Z. Naturforsch. 46c (1991), 993-1000. 


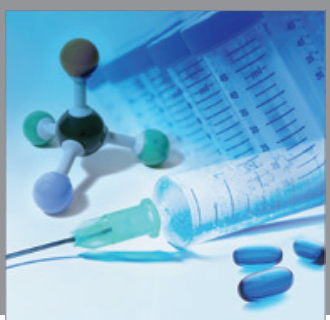

International Journal of

Medicinal Chemistry

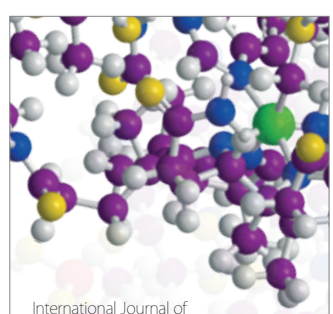

Carbohydrate Chemistry

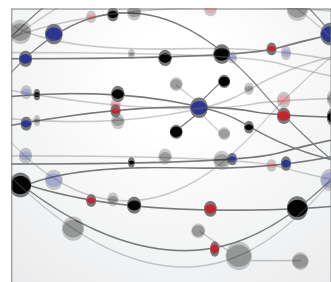

The Scientific World Journal
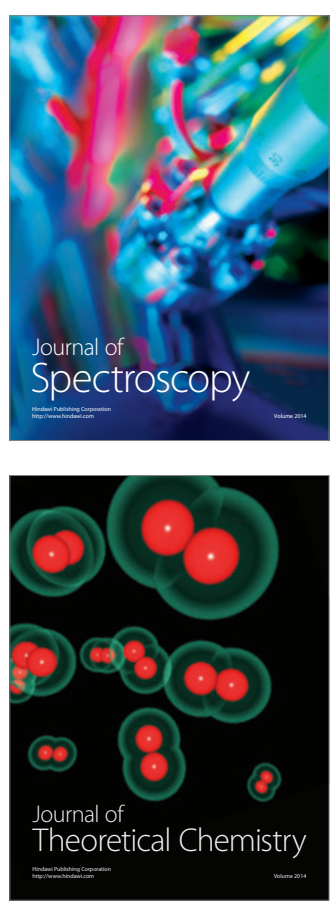
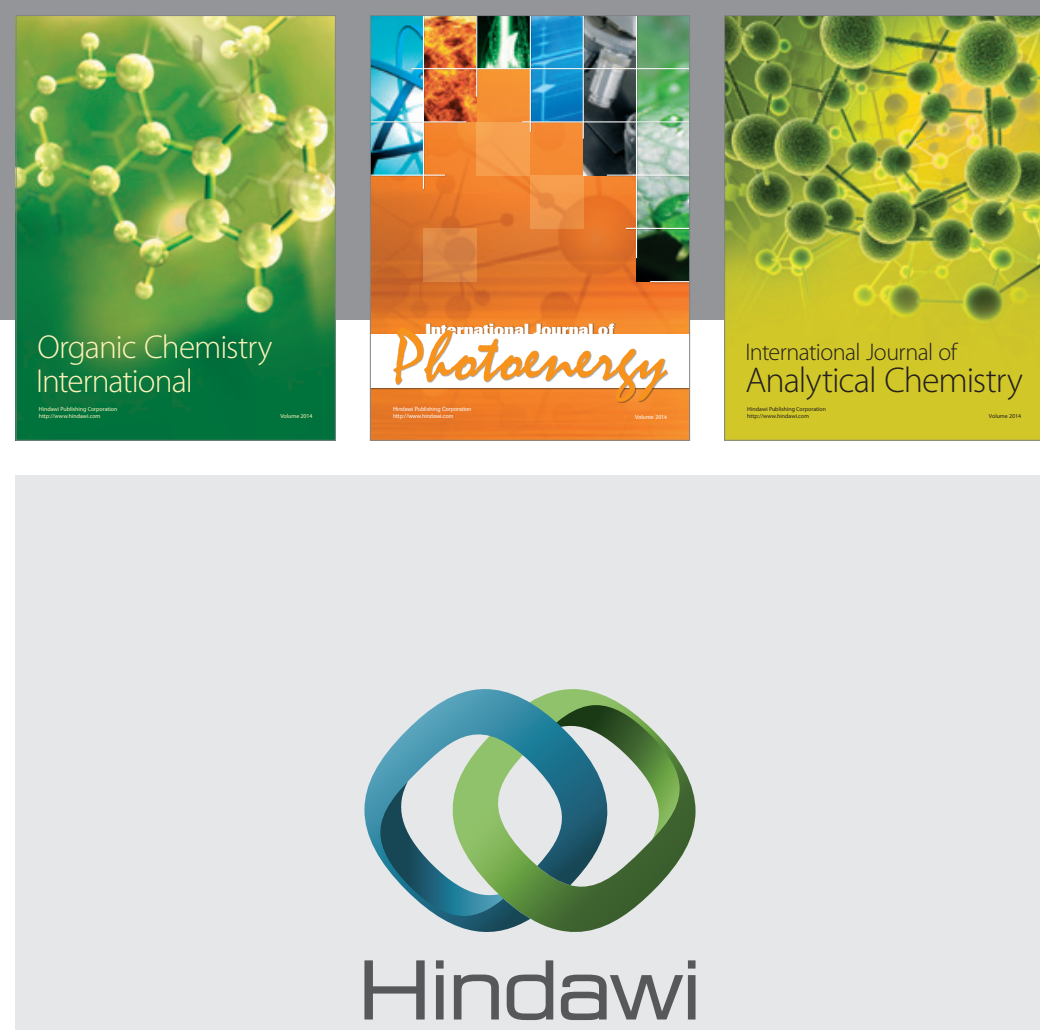

Submit your manuscripts at

http://www.hindawi.com
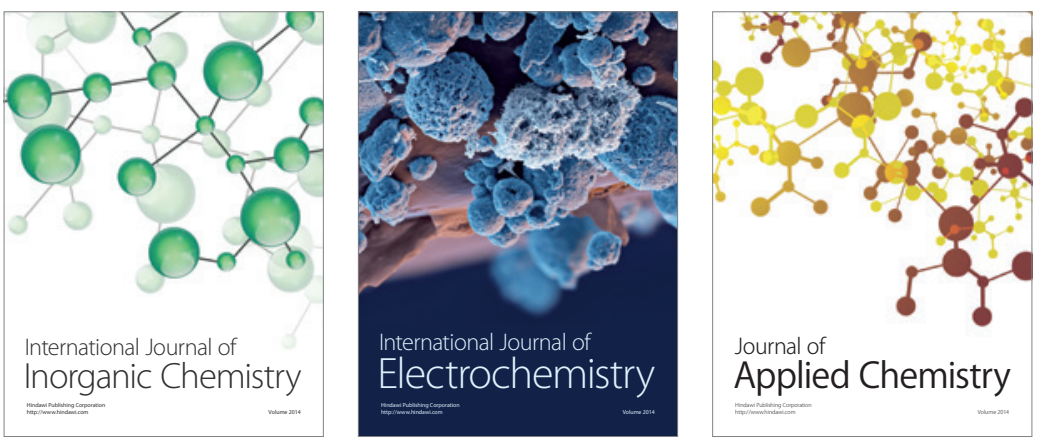

Journal of

Applied Chemistry
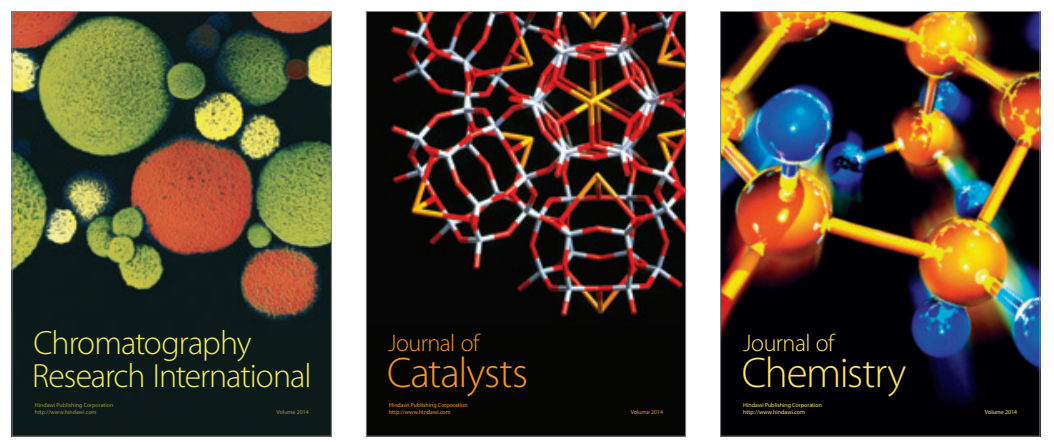
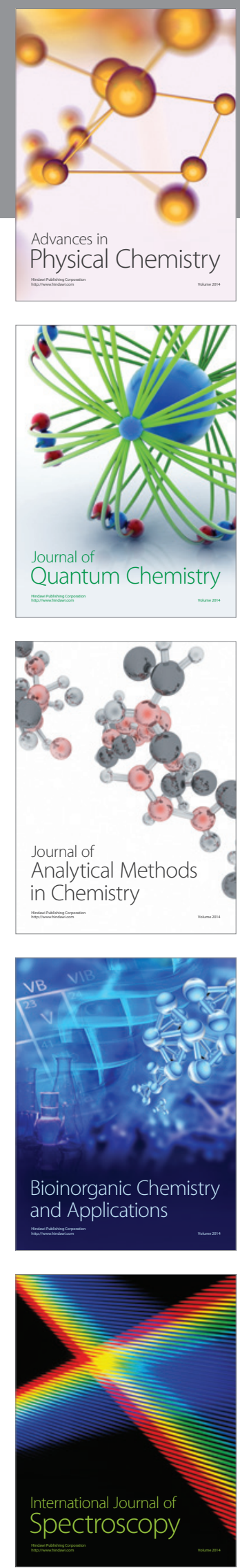